\title{
Latitudinal Differentiation among Modern Planktonic Foraminiferal Populations of Central Mediterranean: Species-Specific Distribution Patterns and Size Variability
}

\author{
George Kontakiotis ${ }^{1, *(\mathbb{D})}$, Eirini Efstathiou ${ }^{1}$, Stergios D. Zarkogiannis ${ }^{2} \mathbb{D}$, Evangelia Besiou ${ }^{1}$ \\ and Assimina Antonarakou ${ }^{2}$ D \\ 1 Department of Historical Geology-Paleontology, Faculty of Geology and Geoenvironment, \\ School of Earth Sciences, National and Kapodistrian University of Athens, Panepistimiopolis, Zografou, \\ 15784 Athens, Greece; euirini@gmail.com (E.E.); evabesiou@geol.uoa.gr (E.B.) \\ 2 Department of Earth Sciences, University of Oxford, Oxford OX1 3AN, UK; \\ stergios.zarkogiannis@earth.ox.ac.uk (S.D.Z.); aantonar@geol.uoa.gr (A.A.) \\ * Correspondence: gkontak@geol.uoa.gr; Tel.: +30-21-0727-4804
}

\section{check for} updates

Citation: Kontakiotis, G.; Efstathiou, E.; Zarkogiannis, S.D.; Besiou, E.; Antonarakou, A. Latitudinal Differentiation among Modern Planktonic Foraminiferal Populations of Central Mediterranean: Species -Specific Distribution Patterns and Size Variability. J. Mar. Sci. Eng. 2021, 9, 551. https://doi.org/10.3390/ jmse9050551

Academic Editor: Wonho Yih

Received: 28 April 2021

Accepted: 18 May 2021

Published: 20 May 2021

Publisher's Note: MDPI stays neutral with regard to jurisdictional claims in published maps and institutional affiliations.

Copyright: (C) 2021 by the authors. Licensee MDPI, Basel, Switzerland. This article is an open access article distributed under the terms and conditions of the Creative Commons Attribution (CC BY) license (https:// creativecommons.org/licenses/by/ $4.0 /)$.
Abstract: Studies of the spatial distribution and size of modern planktonic foraminifera are still lacking in the Mediterranean Sea. In this study, 17 core-top sediments collected from a north-south transect along the central Mediterranean have been analyzed for planktonic foraminiferal content, in terms of their distributional pattern and intraspecific size variability. Among the analyzed planktonic foraminiferal species, Globigerina bulloides and Globigerinoides ruber (w) were the most abundant, presenting an antagonistic behavior and an overall decreasing trend in their average size values from Adriatic to Ionian sub-basins. Intraspecific differences have been also documented for G. ruber (w), with the dominant sensu stricto morphotype to present generally higher frequencies and more constant shell sizes than sensu lato. The greater size variability of the latter is possibly related to its adaptation in particular hydrographic conditions based on its depth habitat preference and ecological characteristics to reach the (sub)optimum growth conditions. The rest of the species occur in minor percentages and show on average $11 \%$ increase with decreasing latitude characterized by distinct species-specific size variations along the transect. Our results show that the relationship between planktonic foraminifera shell size and abundance or sea surface temperature are either absent or weaker than previously reported for other regions and that in central Mediterranean assemblages' size may be mainly related to nutrient availability. Besides the environmental parameters (sea surface temperature, primary productivity, water depth, stratification), the possible hidden cryptic diversity, still lingers to be consistently determined, could give a better understanding of the geographic and morphological differentiation within the Mediterranean planktonic populations.

Keywords: planktonic foraminiferal biogeography; surface sediments; morphometrics; shell size; environmental biomonitoring; ecological optimum conditions; primary productivity; depth habitat preference; cryptic speciation; central Mediterranean hydrodynamics

\section{Introduction}

Foraminifera are one of the most abundant and diverse heterotrophic protists in the oceans consisting of a major group of calcareous marine microplankton [1]. Due to their great abundance and their good fossilization potential, foraminifera are commonly used for bio-ecostratigraphic [2-7], paleoceanographic/paleoclimatic [8-19], and/or paleobiogeographic [20-24] studies. Particularly, planktonic foraminifera are the most frequently applied microfossil group in this manner because they have an excellent fossil record with global distribution, high abundance in sedimentary archives, and further present an enhanced sensitivity to varying sea surface conditions $[25,26]$. The geographic ranges and abundance of these organisms can also provide valuable quantitative and qualitative proxy 
data through the estimation of several paleoceanographic and paleoclimatic indices for reconstructing paleoenvironments [27-29]. Both their abundance and shape-size-related changes are strongly related to surface ocean physico-chemical properties, most notably temperature, but also nutrient and oxygen availability, water column stratification, salinity, turbidity, and carbonate saturation [8,25,30-38]. Elucidation of the factors governing their distribution, and processes involved in their ontogenetic development are therefore essential for reconstructing paleoceanographic conditions.

Compared to the large body of knowledge on the taxonomy, physiology, and ecology of planktonic foraminiferal species, their spatial distribution and size response to hydroclimate remains poorly studied, especially for the oceanic sub-basins and/or marginal seas, which are often more responsive to paleoceanographic and paleoclimatic changes than global oceans. Moreover, as a significant constituent of microzooplankton, they are key components of pelagic food webs and the main predators of phytoplankton in (sub)tropical oligotrophic waters regulating thus the carbon flux in such environments [39-43]. Although at a global scale, their abundance follows the overall pattern of primary productivity (PP; [44]), at a regional scale this relationship is weaker possibly due to the omnivorous diet of the planktonic foraminifera in the marine food web, and phase shifts in the production of phytoplankton and zooplankton [1]. Species abundance varies with season, water mass, and water depth [36]. Both the highest horizontal and vertical separation of species are recorded from temperate to subtropical waters, owing to a wider diversity of meso-scale local hydrographic features and biotic variables, which make their distribution patchy on temporal and spatial scales $[45,46]$.

Based on the species-specific ecological tolerance limits of modern planktonic foraminifera [1,47], the potential reduction in abundance is related to their departure from optimum conditions [48], and the subsequent size-related and/or weight-related changes on the planktonic fauna [49], since planktonic foraminifera must compensate for their greater shell weight to maintain buoyancy [50]. Changes in size can be attributed to different processes (volume or surface area dependent) linked to the ecology of each species [51-53]. Particularly, isometric features increase with the cube of linear dimensions, while surface area-related features increase merely with the square of linear dimensions. Consequently, surface area-dependent processes, such as feeding, respiration, and skeletal support of foraminifera have to keep up with volume and weight changes.

The main goal of this study is to evaluate and further quantify the spatial and sizerelated distribution of modern planktonic foraminifera from the central Mediterranean Sea. In our attempt to better understand the paleoecological and paleobiogeographical significance of size variability in planktonic foraminiferal fauna of Adriatic and Ionian basins, the relative importance of environmental factors controlling rates, magnitudes, spatial scale, and biotic change are also examined. This allows for the establishment of a detailed reference record for the central Mediterranean in terms of planktonic foraminiferal ecosystem functioning (including species composition, diversity, and size variability), providing, on the one hand, a solid eco-morphological microplankton response to environmental conditions for the study area, and facilitating, on the other hand, paleoceanographic correlations at a local (e.g., eastern Mediterranean-Aegean and Levantine basins; [24]) and a global, e.g., [37], scale. 


\section{Study Area}

\subsection{Regional Oceanographic Setting}

The Mediterranean Sea is a land-locked Sea characterized by an anti-estuarine circulation pattern which is forced by negative hydrological balance and density gradient compared to the open Atlantic Ocean [54]. Particularly, the central Mediterranean basin consists of the Adriatic and Ionian Seas (Figure 1), which are characterized by complex geomorphology and oceanography, as well as different productivity regimes. The Adriatic Sea is a small semi-enclosed shelf area connected to the eastern Mediterranean through the Otranto Strait. According to its topography, it presents strong bathymetric contrasts from north to south with its northernmost part being the shallowest $(\sim 50 \mathrm{~m})$, the middle Adriatic deeper ( $270 \mathrm{~m}$ ) and the southern Adriatic the deepest (up to $1250 \mathrm{~m}$ ) [55]. The same exists for the Ionian Sea, which constitutes distinct sub-basins with different bathymetric and hydrological characteristics. For instance, the Salerno area is characterized by a broad continental shelf with rocky bottoms, the Calabrian sector by numerous narrow submarine canyons [56], while the central Ionian by the homonymous abyssal plain. Overall, the Ionian Sea is affected by the inflow of water from the Levantine, Aegean, Adriatic and western Mediterranean basins and therefore different water masses propagate into the Ionian Sea and mixing between them can occur. The general hydrographic conditions determine substantial differences in temperature and salinity values within the study area and the large-scale circulation pattern undergoes seasonal changes resulting in diverse physical, biogeochemical, and ecological conditions $[57,58]$.

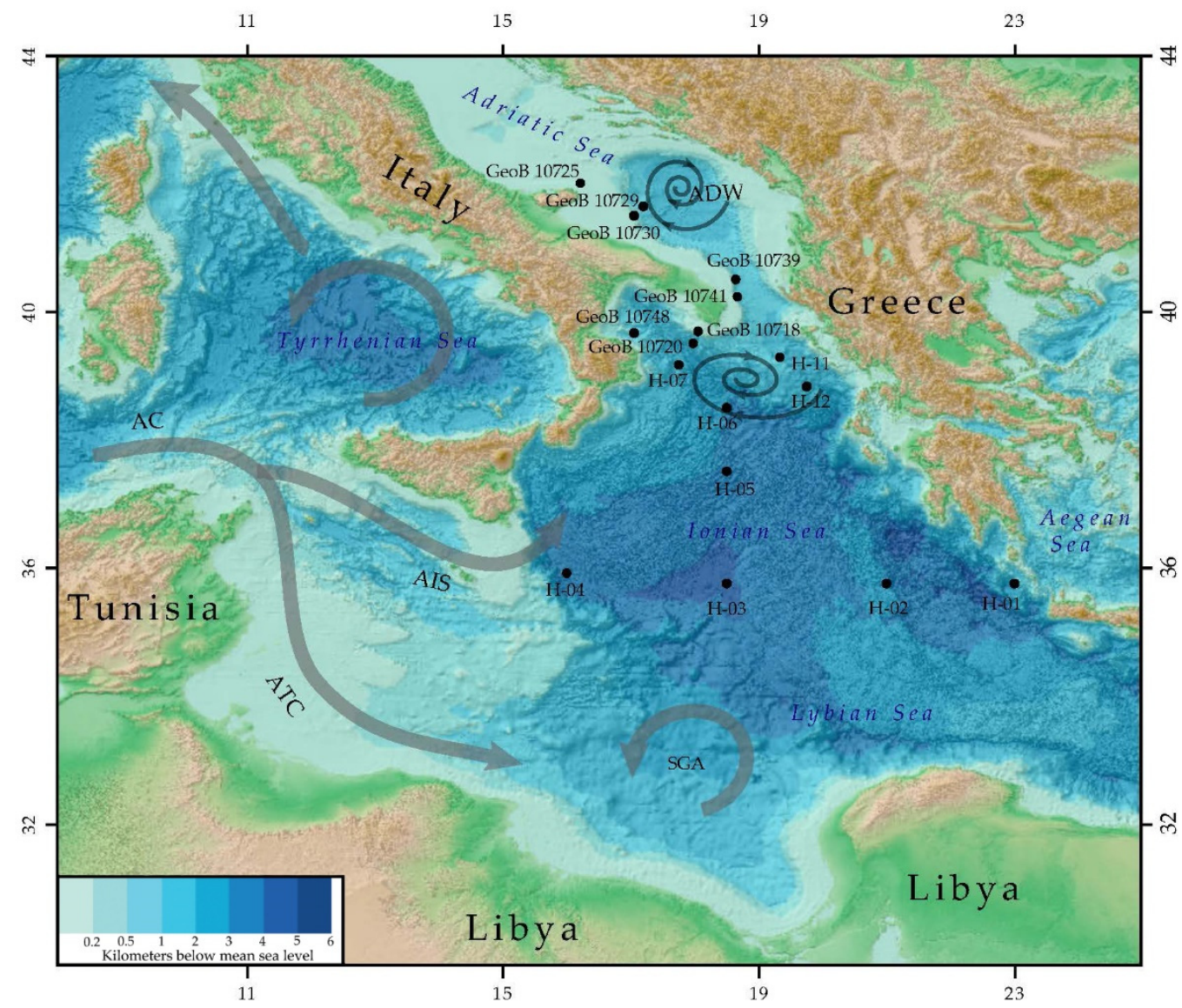

Figure 1. Bathymetric map of the central Mediterranean depicting the sampling locations in the Adriatic and Ionian sub-basins along with the upper ocean current system in the study area. 


\subsection{Water Masses and Circulation}

The Ionian Sea is affected by the inflow of diverse water masses from the Levantine, Aegean, Adriatic, and western Mediterranean. At the entrance of the Sicily Strait, inflowing surface waters occupying the upper $200 \mathrm{~m}$ (Modified Atlantic Water; MAW) flow eastward along the north African coast and separate into two branches: one turns northward along the Sicilian coast into a broad anticyclonic pattern, while the other continues in an easterly direction along the African coast with increasing salinity, following a large-scale counterclockwise pathway $[59,60]$ (Figure 1). The northern branch, called the Atlantic Ionian Stream (AIS; [61]), is complicated by quasi-permanent mesoscale gyres and their spatial variable in terms of shape, position and strength lobes, meanders and transient eddies contributing to the MAW transport into the eastern Mediterranean off the southern coast of Sicily [59,62]. Such meso-scale eddies are often very efficient in transferring particles and passive tracers vertically or horizontally, contributing in this way to the propagation and mixing of water masses. The eastern-most MAW, termed Atlantic Tunisian Current (ATC; [63]), shows a marked path in winter when it cools and undergoes a severe salt enrichment forming the Levantine Intermediate Water (LIW). The LIW, enriched by Cretan intermediate water, flows westward into the Tyrrhenian Sea at 200-600 m depth as the salty outflow waters. Its role is particularly important since it is the preconditioning agent for the dense water formation of both the Adriatic Deep Water (AdDW) and Aegean Deep Water (AeDW) below $800 \mathrm{~m}[60,64-66]$ and their communication to the western Mediterranean basin [67].

The surface circulation of the Adriatic Sea consists of a basin-wide and seasonal variable cyclonic gyre with a northward flow along the eastern side, the Eastern Adriatic Current (EAC; [68]), and a southward return flow along the Italian coast on the western side (Western Adriatic Current; WAC; [69]) which flushes the nutrient-rich water out of the northern Adriatic [70]. During autumn and winter, a cold and relatively fresh dense water mass (AdDW) is also formed in the northern and central Adriatic Sea. Outflowing AdDW is accompanied by inflowing warmer LIW from the Ionian Sea, and this thermal circulation is driven by winter cooling of the Adriatic [71]. Overall, there are three main forcing factors affecting the circulation pattern: (a) river runoff causing heat loss and low-salinity water gain; (b) atmospheric forcing responsible for dense water formation and seasonal differences in circulation; and (c) exchange via the Strait of Otranto balancing the water budget by the intrusion of warm and salty waters from the Ionian Sea. As a result, temperature, salinity and circulation display marked spatial and temporal variations [72]. Moreover, the Adriatic Sea typically presents lower surface salinities than the rest of the central Mediterranean, mostly due to large freshwater inputs from rivers, acting as a dilution basin [73].

\subsection{Productivity Regimes}

River runoff affects the circulation through freshwater input and impacts the marine ecosystem by introducing large amounts of organic matter, nutrients, and sediments. Particularly, Po and Apennine rivers play a major role in freshwater supply for the northern Adriatic. Beyond the seasonal character of river discharges, the long-term changes of nutrient concentrations in the northern Adriatic are also strongly influenced by atmospheric conditions and therefore connected with climatic fluctuations, which can modify the water column dynamics (e.g., vertical mixing, horizontal advection, water exchange rate between north-central Adriatic; [74]). The southern Adriatic open waters show oligotrophic characteristics comparable to the Ionian Sea, with nutrient supply to the euphotic zone strongly depending on vertical stratification and mixing processes [75]. However, higher phytoplankton densities have been observed in the surface waters along the south Italian coasts driven by intensified freshwater inputs [76,77]. Horizontal or vertical advection of nutrient-rich LIW from the Ionian Sea is also an important productivity factor [78] for specific locations within the southern Adriatic Sea where phytoplankton blooms follow deep convection events [79]. Physical and chemical parameters of these blooms [80] have 
shown a switch from typical Mediterranean phosphorous- to nitrogen-limited conditions for this setting.

\section{Materials and Methods}

\subsection{Sediment Sampling Strategy and Site Selection}

The study is based on the micropaleontological analysis of the distribution abundance pattern and size variability of the planktonic foraminiferal fauna in a series of modern core-tops derived from 17 surface sediment sites across the central Mediterranean Sea. The samples were collected by multicores during various expeditions (POSEIDON cruise "CAPPUCCINO" in June 2006, Meteor cruise M71/3 in January 2007) and cover a latitudinal NW-SE transect from the north Adriatic to the south Ionian Sea, spanning variable sea surface parameters, different productivity regimes, and a wide depth range between 94 and $4088 \mathrm{~m}$ (Table 1 and Figure 1). Their chronology is based on ${ }^{210} \mathrm{~Pb}$ and ${ }^{137} \mathrm{Cs}$ radiometric dating applied on some of the present samples [81] and surrounding core-tops [82,83]. Although generally the core-top samples provide integrated information on a longer time scale (decades, centuries or millennials depending on the sedimentation rate of the selected sites) compared to the water column (e.g., plankton tow, sediment traps) derived samples, the relatively low $\left(0.06-0.91 \mathrm{~cm} \mathrm{yr}^{-1}\right.$, avg. $0.19 \mathrm{~cm} \mathrm{yr}^{-1}$; [77]) sedimentation rates (likely decrease with distance from the shore) in conjunction with the constant sediment accumulation rate over the last century that characterizes the central Mediterranean surface sediments [84] corroborate the recent character of the analyzed samples. Accordingly, all studied core tops are suggested to have a modern age and in accordance with other core-top studies within the Mediterranean Sea $[18,20,24,77,85,86]$. Thus, our dataset represents an integrated record of some yr to $50 \mathrm{yr}$ or a few $100 \mathrm{yr}$ at most, depending on the core location. The multicore provided topmost $(0-1 \mathrm{~cm})$ sediments with an undisturbed sediment-water interface. More explicitly, we use 6 core-top samples along the south Adriatic Sea from the Gargano Promontory to the Strait of Otranto, supplemented by additional 11 samples from the entire Ionian basin (from the Gulf of Taranto to the Mediterranean Ridge offshore Crete Island).

Given the availability of processed sediment samples with well-preserved foraminifera, the analyzed core-tops are further carefully selected based on the major circulation features in Adriatic and Ionian basins as well as the Italian river influences. Therefore, they are strategically positioned to check the sensitivity of environmental parameters and the subsequent planktonic foraminiferal fauna responses by assessing the adaptability of each species, including both species-specific distribution patterns and size variations, to different environmental regimes. For this reason, relative abundances and size offsets have been interpreted in regard to upper water chlorophyll-a (Chl-a) concentrations and mean annual sea surface temperature (SST), salinity (SSS), and density values of the central Mediterranean water masses. SST and SSS data were derived from the Emodnet database (https: / / portal.emodnet-physics.eu/) (15 December 2020) of the years 1900-2013, while density data obtained from the National oceanic and atmospheric administration dataset (https:/ / www.ncei.noaa.gov/access/world-ocean-atlas-2018/bin/woa18.pl) (15 December 2020) on a $0.1^{\circ}$ grid resolution. The Chl-a concentrations at each core location were used as satellite data retrieved from OBPG MODIS-Aqua Monthly Global $4 \mathrm{~km}$ database (http:/ / oceancolor.gsfc.nasa.gov) (15 December 2020) for the time period 4 September 2002 to 30 June 2020 (Table 1). 
Table 1. Core-top locations, coordinates, scientific expeditions, seafloor water depths, lithology, and mean annual SST, SSS and density data along with Chl-a concentrations.

\begin{tabular}{|c|c|c|c|c|c|c|c|c|c|c|}
\hline Cruise & Station & Latitude & Longitude & Basin (Region) & $\begin{array}{l}\text { Water } \\
\text { Depth }\end{array}$ & Lithology & SST & SSS & Ch-a & $\begin{array}{c}\text { Density } \\
\sigma_{\theta} \\
\end{array}$ \\
\hline & & $\left({ }^{\circ} \mathrm{N}\right)$ & $\left({ }^{\circ} \mathrm{E}\right)$ & & (m) & & ${ }^{\circ} \mathbf{C}$ & psu & $\mathrm{kgCm}^{-2} \mathrm{yr}^{-1}$ & $\left(\mathrm{~kg} / \mathrm{m}^{3}\right)$ \\
\hline $\begin{array}{l}\text { Poseidon } \\
\text { P339 }\end{array}$ & $\begin{array}{l}\text { \#17. GeoB } \\
10725\end{array}$ & 42.001 & 16.217 & $\begin{array}{l}\text { Gargano Promontory } \\
\text { (S. Adriatic Sea) }\end{array}$ & 94 & Mud & 14.40 & 38.29 & 0.42 & 28.65 \\
\hline $\begin{array}{l}\text { Poseidon } \\
\text { P339 }\end{array}$ & $\begin{array}{l}\# 16 . \text { GeoB } \\
10729\end{array}$ & 41.647 & 17.191 & $\begin{array}{l}\text { Gargano Promontory } \\
\text { (S. Adriatic Sea) }\end{array}$ & 708 & $\begin{array}{l}\text { Sandy } \\
\text { mud }\end{array}$ & 13.40 & 38.60 & 0.19 & 29.10 \\
\hline $\begin{array}{l}\text { Poseidon } \\
\text { P339 }\end{array}$ & $\begin{array}{c}\# 15 . \text { GeoB } \\
10730\end{array}$ & 41.500 & 17.050 & $\begin{array}{l}\text { Gargano Promontory } \\
\text { (S. Adriatic Sea) }\end{array}$ & 179 & $\begin{array}{l}\text { Sandy } \\
\text { mud }\end{array}$ & 13.90 & 38.70 & 0.21 & 29.07 \\
\hline $\begin{array}{l}\text { Poseidon } \\
\text { P339 }\end{array}$ & $\begin{array}{c}\# 14 . \text { GeoB } \\
10739\end{array}$ & 40.500 & 18.642 & $\begin{array}{l}\text { Strait of Otranto } \\
\text { (S. Adriatic Sea) }\end{array}$ & 561 & Mud & 13.80 & 38.73 & 0.24 & 29.12 \\
\hline $\begin{array}{l}\text { Poseidon } \\
\text { P339 }\end{array}$ & $\begin{array}{c}\# 13 . \text { GeoB } \\
10741\end{array}$ & 40.234 & 18.667 & $\begin{array}{l}\text { Strait of Otranto } \\
\text { (S. Adriatic Sea) }\end{array}$ & 286 & $\begin{array}{l}\text { Sandy } \\
\text { mud }\end{array}$ & 14.00 & 38.67 & 0.28 & 29.03 \\
\hline $\begin{array}{l}\text { Poseidon } \\
\text { P339 }\end{array}$ & $\begin{array}{l}\# 12 . \mathrm{GeoB} \\
10718\end{array}$ & 39.693 & 18.058 & $\begin{array}{l}\text { Gulf of Taranto } \\
\text { (NW Ionian Sea) }\end{array}$ & 214 & $\begin{array}{l}\text { Sandy } \\
\text { mud }\end{array}$ & 14.20 & 38.32 & 0.27 & 28.71 \\
\hline $\begin{array}{l}\text { Poseidon } \\
\text { P339 }\end{array}$ & $\begin{array}{l}\# 11 . \text { GeoB } \\
10748\end{array}$ & 39.667 & 17.050 & $\begin{array}{l}\text { Strait of Otranto } \\
\text { (S. Adriatic Sea) }\end{array}$ & 284 & Mud & 13.80 & 38.73 & 0.25 & 29.12 \\
\hline $\begin{array}{l}\text { Poseidon } \\
\text { P339 }\end{array}$ & $\begin{array}{c}\# 10 . \text { GeoB } \\
10720\end{array}$ & 39.507 & 17.979 & $\begin{array}{l}\text { Gulf of Taranto } \\
\text { (NW Ionian Sea) }\end{array}$ & 1384 & Mud & 13.60 & 38.69 & 0.19 & 29.13 \\
\hline $\begin{array}{l}\text { Meteor } \\
\text { M 71-3 }\end{array}$ & \#9. H-11 & 39.283 & 19.333 & $\begin{array}{c}\text { Offshore Kerkyra } \\
\text { basin (NE. Ionian Sea) }\end{array}$ & 1032 & $\begin{array}{l}\text { Muddy } \\
\text { sand }\end{array}$ & 13.60 & 38.70 & 0.15 & 29.14 \\
\hline $\begin{array}{l}\text { Meteor } \\
\text { M 71-3 }\end{array}$ & \#8. H-07 & 39.167 & 17.750 & $\begin{array}{l}\text { External Calabrian } \\
\text { Arc (NW. Ionian Sea) }\end{array}$ & 1663 & Mud & 13.60 & 38.69 & 0.18 & 29.13 \\
\hline $\begin{array}{l}\text { Meteor } \\
\text { M 71-3 }\end{array}$ & \#7. H-12 & 38.833 & 19.750 & $\begin{array}{c}\text { Offshore Kerkyra } \\
\text { basin (NE. Ionian Sea) }\end{array}$ & 1459 & Clay & 13.60 & 38.70 & 0.14 & 29.14 \\
\hline $\begin{array}{l}\text { Meteor } \\
\text { M 71-3 }\end{array}$ & \#6. H-06 & 38.500 & 18.500 & $\begin{array}{l}\text { Ionian Bathyal Plain } \\
\text { (N. Ionian Sea) }\end{array}$ & 3018 & Clay & 13.80 & 38.71 & 0.14 & 29.10 \\
\hline $\begin{array}{l}\text { Meteor } \\
\text { M 71-3 }\end{array}$ & \#5. H-05 & 37.500 & 18.500 & $\begin{array}{l}\text { Ionian Bathyal Plain } \\
\text { (C. Ionian Sea) }\end{array}$ & 3157 & Mud & 13.90 & 38.72 & 0.12 & 29.09 \\
\hline $\begin{array}{l}\text { Meteor } \\
\text { M 71-3 }\end{array}$ & \#4. H-04 & 35.917 & 16.000 & $\begin{array}{l}\text { External Calabrian } \\
\text { Arc (W. Ionian Sea) }\end{array}$ & 3747 & $\begin{array}{l}\text { Muddy } \\
\text { sand }\end{array}$ & 13.80 & 38.67 & 0.14 & 29.07 \\
\hline $\begin{array}{l}\text { Meteor } \\
\text { M 71-3 }\end{array}$ & \#3. H-01 & 35.750 & 23.000 & $\begin{array}{l}\text { Offshore Cretan basin } \\
\text { (E. Ionian Sea) }\end{array}$ & 2121 & Clay & 14.10 & 38.83 & 0.11 & 29.13 \\
\hline $\begin{array}{l}\text { Meteor } \\
\text { M 71-3 }\end{array}$ & \#2. H-02 & 35.750 & 21.000 & $\begin{array}{l}\text { Mediterranean Ridge } \\
\text { (C. Ionian Sea) }\end{array}$ & 3005 & Clay & 13.90 & 38.74 & 0.09 & 29.10 \\
\hline $\begin{array}{l}\text { Meteor } \\
\text { M 71-3 }\end{array}$ & \#1. H-03 & 35.750 & 18.500 & $\begin{array}{l}\text { Ionian Bathyal Plain } \\
\text { (C. Ionian Sea) }\end{array}$ & 4088 & Clay & 13.80 & 38.67 & 0.10 & 29.07 \\
\hline
\end{tabular}

\subsection{Micropaleontological Quantitative Analysis}

The planktonic foraminiferal assemblages for the studied core-tops were picked from $10 \mathrm{~cm}^{3}$ of wet sediment after washing through a $125 \mu \mathrm{m}$ mesh sieve and cleaning using the HyPerCal protocol [87]. The $125 \mu \mathrm{m}$ size fraction was selected in order to increase the reliability of studied planktonic foraminiferal assemblages that derived from such a subtropical oligotrophic-to-mesotrophic region with relatively low planktonic foraminiferal abundance $[22,88,89]$ by avoiding over/under-estimations in the percentages of smaller (e.g., Turborotalita quinqueloba) or larger (e.g., Trilobatus trilobus) in size than the usual mean size of other species. The adopted size fraction is commonly used in relevant investigations within and beyond the Mediterranean Sea, which analyze the modern foraminiferal record $[21,24,90-92]$ and implement a paleoclimatic analysis $[8,9,93,94]$. The dry residues $(\sim 3 \mathrm{~g})$ were split using an Otto micro-splitter into aliquots of at least 300 planktonic foraminiferal specimens, which were identified to the species level according to the taxonomic concepts of Hemleben et al. [1] and Schiebel and Hemleben [95]. Raw data were transformed into percentages of the total absolute abundance, and relative percentage abundance curves were plotted versus latitude. Following Aurahs et al. [96], we distinguish Globigerinoides ruber pink (var. rosea) as a distinct morphotype, whereas for the white variety (var. alba), we follow the concept of Wang [97] by distinguishing G. ruber sensu stricto (s.s.) and G. ruber sensu lato (s.l.) morphotypes which have different depth preferences [98] and reflect distinctive environmental parameters [99,100]. We further note that G. ruber s.s. is equivalent to Morphotype A (type "Normal"), while those specimens 
are grouped as G. ruber s.l. correspond to the Morphotypes B and C (type "Platys" and "Elongate") of Kontakiotis et al. [21] from the Mediterranean Sea. The Globigerina bulloides group includes the species G. bulloides and G. falconensis due to their similar ecological preferences [95]. Finally, the ecological interpretations and biogeographic implications for the studied species were based on the reference of [22,24,101-103].

\subsection{Morphometric Analysis}

For morphometric analysis, the picked specimens were transferred with a brush on a chapman micro-slide, where each species positioned in separate cells. Given the minimized difference in average areas for the umbilical or spiral sides for several species [104], we oriented the foraminiferal shells in umbilical or spiral position (species dependent) to capture the maximum silhouette area of each individual. The fixed specimens were photographed in transmitted light under a 50-fold magnification by a modular Leica M165 C fully apochromatic stereo microscope equipped with an integrated 10 megapixel (MP) Leica IC90 E color camera and processed using ImageJ software (version 1.50i). The derived images were parsed into objects by thresholding and their shape and size parameters were automatically extracted. Automated recognition of multiple foraminifera in the images was succeeded due to the contrast between the bright background and the dark silhouettes of the specimens. Following the pioneer work of Kucera and Kennett [105] and in accordance with a recent study of Zarkogiannis et al. [24] for the eastern Mediterranean, the Equivalent Circular Diameter (ECD) was measured as an aspect of the size of the species analyzed. Calibration for the silhouette area and diameter measurements was performed using a microscale image taken at the same magnification as the foraminiferal images optimizing the reproducibility and accuracy of the measurements. Additional to size analysis, image processing automatically performs planktonic foraminiferal counting, as well for each site, resulting in the overall changes in their assemblages for the study area during recent times.

\section{Results}

\subsection{Relative Abundance Data}

Thirteen planktonic foraminiferal species were identified at the studied core-tops along the N-S transect of the central Mediterranean Sea. The overall changes in their abundances are illustrated in Figure 2. Overall, the planktonic assemblages are dominated by G. bulloides, followed by G. ruber (including var. alba and rosea), while the species Globigerinella siphonifera, Neogloboquadrina pachyderma, Orbulina universa, Globoturborotalita rubescens, and Globigerinita glutinata are common. Globorotalia inflata, Globorotalia truncatulinoides and Turborotalita quinqueloba display a more sporadic faunal pattern with lower percentages.

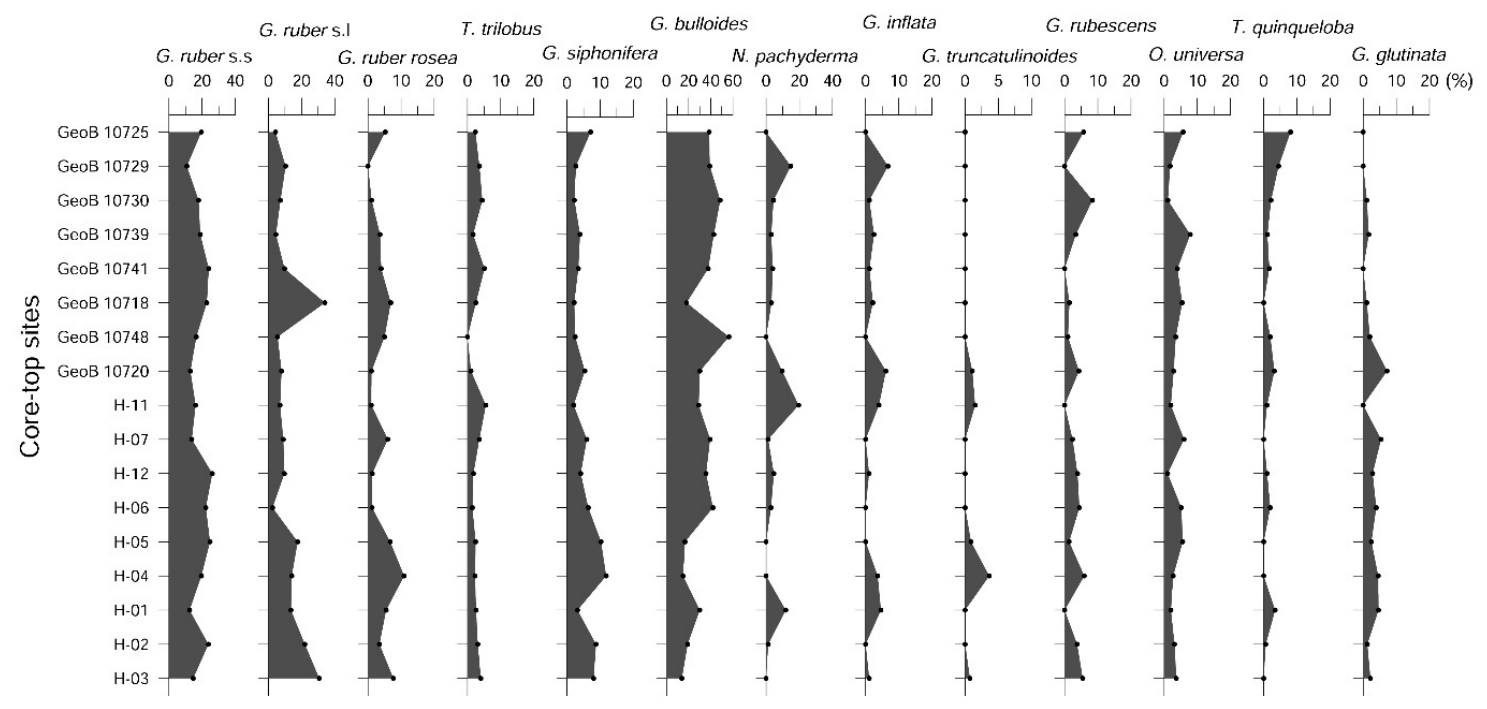

Figure 2. Planktonic foraminifera species abundances in core-top samples from the eastern Mediterranean. The labels in the vertical axis are representative of the core-top locations presented in Table 1. 
G. bulloides is the major contributor in the planktonic fauna in all samples with percentages up to $57 \%$. However, the average contribution of this species significantly differs between the two study regions with a clear geographic signal to have emerged in its distribution. More explicitly, a sharp decrease in the abundance of G. bulloides with latitude is marked with the average values of $43.9 \%$ for the Adriatic to be diminished to $26.3 \%$ for the Ionian basin, respectively. It reaches high abundance values, constantly higher than $35 \%$ within the south Adriatic Sea, while its distributional pattern displays minor (almost half) percentages in the Ionian basin. Globigerinoides ruber $(\mathrm{w})$ is the second ubiquitous and more abundant species showing an average abundance of $29.8 \%$ in the central Mediterranean. This species is continuously present throughout the transect, displaying almost an opposite distributional pattern compared to G. bulloides. Such an antagonistic pattern is documented for both s.s. and s.l. morphotypes. Except for two samples (H-03 and GeoB 10718), the s.s. morphotype is the main constituent in the G. ruber (w) morphospace. This intra-specific trend is more pronounced in the Adriatic basin, where the dominant morphotype presents higher frequencies (i.e., at least the double percentages) compared to G. ruber s.l. in most of the samples. Globigerinoides ruber rosea is present in lower percentages up to $11 \%$ being more abundant in the southern part of the Ionian basin. Globigerinella siphonifera is present in almost all locations, but its percentages become important by exceeded $10 \%$ only in the westernmost sites $(\mathrm{H}-04, \mathrm{H}-05)$ within the Ionian basin. Neogloboquadrina pachyderma presents a highly variable distributional pattern, occasionally reaching significant percentages up to $20 \%$ (i.e., site H-11 at the northernmost part of the Ionian basin). Orbulina universa, G. rubescens, and T. trilobus show comparable patterns with continuous although limited presence $(<8 \%)$ in both basins. Globigerinita glutinata is mostly found within the Ionian basin with restricted occurrence in relatively small percentages $(<7 \%)$, and it is almost absent in the southern Adriatic Sea. Turborotalita quinqueloba, where present, exists with very small percentages around 3\%. Globorotalia inflata shows a geographically sporadic distribution pattern with percentages stably less than $10 \%$ and the deep-dweller $G$. truncatulinoides is nearby absent from all regions, since it occasionally occurred at very low percentages (maximum $4 \%$ ).

\subsection{Preservation Regime and Size Variability}

The presence of pristine specimens of the tiny thin-walled species reinforces the recent character of the analyzed material and further indicates the excellent preservation of the samples, suggesting that the reported assemblages are not biased by dissolution. The absence of differential preservation of thin-walled specimens of the analyzed species along with the strong carbonate preservation potential of the study area [106] indicate minimized modifications on the size spectrum of the planktonic association.

The mean population size of the identified planktonic foraminifera along with the standard deviation values of species-specific sizes reflecting the overall variability per basin analyzed are summarized in Table 2, while the species-specific size variations along the study transect are shown in Figure 3. The number of individuals measured per species varied from 2 to 170, averaging 21 individuals per species per sample. Generally, the mean population size of the analyzed planktonic foraminiferal assemblages is skewed toward larger sizes from north to south. Our dataset reports a $4-16 \%$ increase (avg 11\%) for all species from Adriatic to Ionian settings, except for G. ruber (including both chromotypes and morphotypes) and G. bulloides, which support the opposite pattern (Table 2). The most consistent in size within the central Mediterranean sub-basins with the smallest standard deviation between analyzed samples are the populations of G. bulloides, G. ruber (s.s. and s.1.), and G. rubescens based on the number of specimens measured. 
Table 2. Intraspecific ECD ranges and their average values (in $\mu \mathrm{m}$ ) per basin analyzed. nd: not determined.

\begin{tabular}{ccccc}
\hline \multirow{2}{*}{ Species } & \multicolumn{2}{c}{ ECD Range } & \multicolumn{2}{c}{ Average ECD } \\
\cline { 2 - 5 } & Adriatic Sea & Ionian Sea & Adriatic Sea & Ionian Sea \\
\hline Globigerinoides ruber s.s. & $125-419$ & $130-377$ & 229 & 223 \\
Globigerinoides ruber s.l. & $162-417$ & $157-469$ & 308 & 269 \\
Globigerinoides ruber rosea & $135-574$ & $126-579$ & 344 & 302 \\
Trilobatus trilobus & $129-561$ & $127-569$ & 273 & 284 \\
Globigerinella siphonifera & $125-544$ & $125-689$ & 273 & 306 \\
Globigerina bulloides & $135-414$ & $126-364$ & 227 & 217 \\
Neogloboquadrina pachyderma & $130-392$ & $127-400$ & 213 & 234 \\
Globorotalia inflata & $162-551$ & $171-612$ & 303 & 357 \\
Globorotalia truncatulinoides & nd & $153-818$ & nd & 435 \\
Globigerina rubescens & $130-207$ & $128-259$ & 169 & 191 \\
Orbulina universa & $153-814$ & $174-905$ & 414 & 496 \\
Turborotalita quinqueloba & $126-199$ & $127-252$ & 166 & 175 \\
Globigerinita glutinata & $126-211$ & $125-315$ & 165 & 197 \\
\hline
\end{tabular}

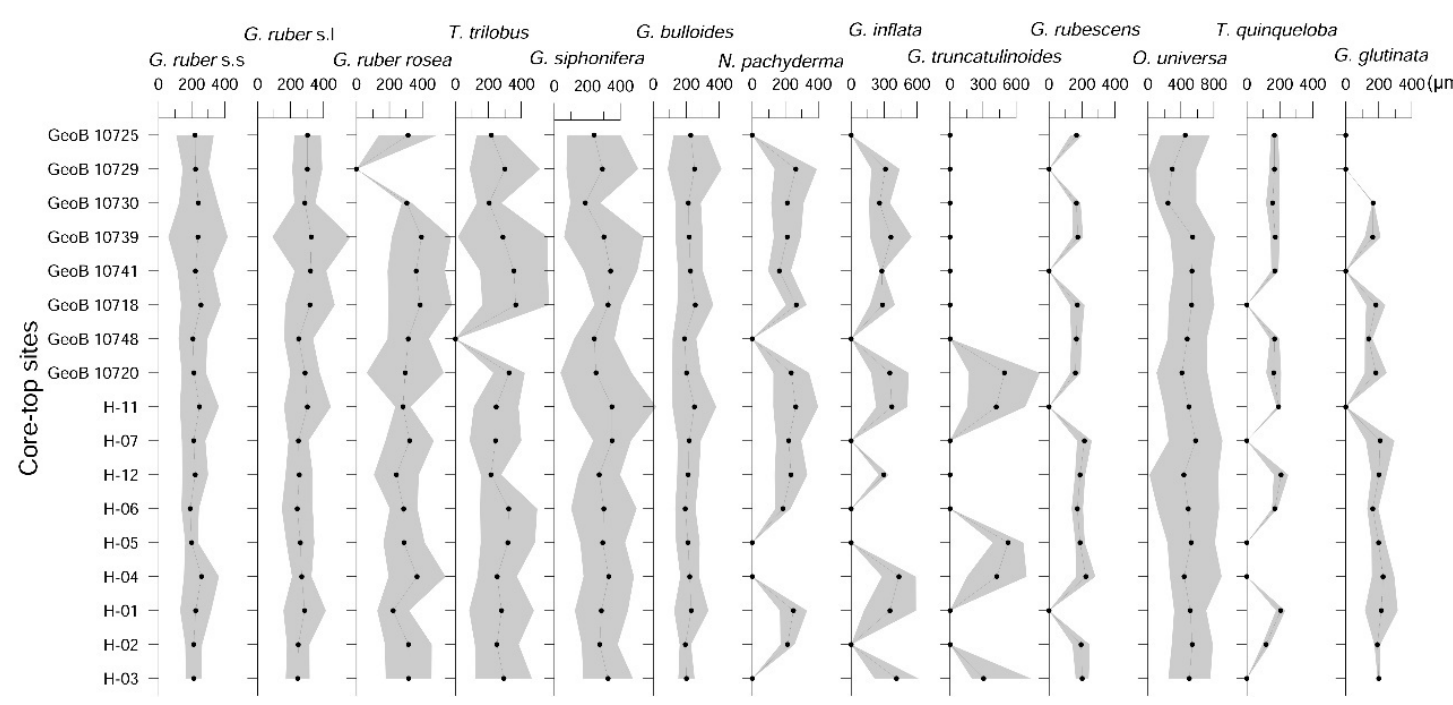

Figure 3. Average population size of the planktonic foraminifera species identified together with their overall population size. The gray shaded areas denote one standard deviation. The labels in the vertical axis are representative of the core-top locations presented in Table 1.

Orbulina universa population is the largest one in both study basins, even more than $G$. truncatulinoides and G. inflata which are followed (Table 2). Spherical shells of O. universa reflected by their ultimate chamber that covers all the previous ones of the pre-adult trochospiral stages seem to be very voluminous in the Ionian as well as in Adriatic basins. Our results from the central Mediterranean show an inverse correlation between shell size and latitudinal occurrence since their average shell diameters increase from the Adriatic $(414 \mu \mathrm{m})$ to the Ionian Sea $(496 \mu \mathrm{m})$. A closer view of the central Mediterranean dataset, regarding this species, indicates an intra-basin latitudinal relationship to the shell size, with the smallest specimens (avg. $=414 \mu \mathrm{m}$ ) occurring in the south Adriatic basin, intermediate values (avg. $=491 \mu \mathrm{m}$ ) are recorded in the north Ionian sub-basin and the largest specimens (avg. $=503 \mu \mathrm{m}$ ) are found in the south Ionian sub-basin. Next in size is G. ruber rosea, which is significantly larger than the white variety of the same species, similar to what was found in the Aegean and Levantine sub-basins [24].

The oligotrophic, symbiont-bearing species T. trilobus and G. siphonifera present similar shell sizes, indicating that they thrive in the same water masses constrained mostly by the same productivity regime of the surface waters. Within $G$ ruber $(w)$ morphospace, the 
sensu lato appears larger (by $20 \%$ ) than the sensu stricto populations. This seems reliable since the former includes the mixing of Platys and Elongate specimens (morphotypes B and C of Kontakiotis et al. [21]). Neogloboquadrina pachyderma and G. bulloides present quite similar intermediate-sized average values of about $220-230 \mu \mathrm{m}$, probably correlating with the same levels of primary productivity of the sub-surface waters. Finally, the species T. quinqueloba, G. glutinata and G. rubescens are the smallest ones recording ECD values less than $200 \mu \mathrm{m}$. Although the two first species are known from the literature as small-sized foraminifera, our results show that G. rubescens can also be added to this group confirming the previous observations of Al-Sabouni et al. [82] and Zarkogiannis et al. [24] from the Atlantic Ocean and the eastern Mediterranean Sea regarding its small size.

\section{Discussion}

\subsection{Ecological and Oceanographic Context of the Planktonic Foraminiferal Biogeographic Distribution in Adriatic and Ionian Basins}

Changes in oceanographic parameters could lead to a geographic offset among modern planktonic associations that may lead to differential abundance patterns and/or shell mass variability towards the optimum growth conditions, modifying the size spectrum of the entire population $[20,21,24,49,89,107]$. Therefore, the assessment of the dominant environmental parameters controlling the planktonic foraminiferal communities within the Mediterranean Sea, such as SST, SSS, and PP $[8,28,89,108,109]$, along with their correlation with the ecological characteristics of the identified species are crucial for explaining the offsets mentioned above.

Although the Adriatic and the Ionian sub-basins are quite similar from the faunistic point of view, some differences seem to exist regarding the abundance of the most significant species. Both sub-basins are dominated by G. bulloides and G. ruber (w), which exhibit an antagonistic faunal pattern. The maximum abundance peaks of G. ruber (s.s. and s.l.) are coincident with minimum relative peaks of G. bulloides in the Ionian basin, while the opposite trend is recorded for the Adriatic Sea (Figure 3), indicating the partly replacement between these species in the planktonic fauna. The high percentages of the opportunistic species G. bulloides are controlled by phyto- and zoo-plankton blooms [22] mainly attributed to the fertilizing effect to the Po River discharge waters and additional local eastern Italian freshwater inputs in the south Adriatic Sea. On the contrary, relative abundance of this species gradually decreases within the Ionian Sea, where the plume waters lose their characteristic features when mixed with other south-eastern Mediterranean surface waters. Globigerinoides ruber is evenly abundant by showing a continuous presence throughout the study transect, due to its ability to withstand large fluctuations in temperature and salinity of the water column $[22,110]$. Its slightly higher contribution (including both morphotypes) in the Ionian basin (Figure 3) could be attributed to more favorable (compared to those of the Adriatic Sea) conditions for its flourishment in the more oligotrophic water column. We highlight that such growth optimum conditions based on depth habitat preference and environmental parameters would certainly help to explain the observed regionally variable abundance patterns of the analyzed morphotypes.

The observed dominance of the normal morphotype in central Mediterranean subbasins possibly is due to its depth and ecological characteristics. G. ruber s.s. has a very constant depth habitat (top 30-50 m; $[99,111,112]$ ) and prefers a temperature- and salinitystratified environment [113], which in the study area is attained by the halocline due to riverine inputs and/or the seasonal thermocline due to surface warming during late spring to early fall. The less abundant $G$. ruber s.l. reaches its highest percentages in sample GeoB 10,718 south of the strait of Otranto and at sites H02, H03, and H-05 in the central-eastern part of the Ionian basin, where recurrent or transient small-scale cyclonic and anticyclonic gyres are formed and enhance the primary productivity (eastern Ionian bloom of D'Ortenzio, et al. [114]), which primarily controls its distribution [21,100]. The intermittent nature of these localized blooms (known as "intermittently blooming areas" of D'Ortenzio and Ribera d'Alcalà [115]) due to their pronounced interannual variability in the spatial shape and timing [114], in combination with the seasonal control of primary 
production trapped at the subsurface Deep Chlorophyll Maximum (DCM) layer [116], which is estimated to be at times even more important than surface production in such oligotrophic setting [117], could be considered the most plausible explanations for their slight record in the satellite-sensed Chl-a data in the study area [114,115]. Moreover, satellite data provide no information on subsurface production, which is known to be important in the eastern part of the Mediterranean and does not always match the timing of surface Chl-a peaks [118] (Figure 4).
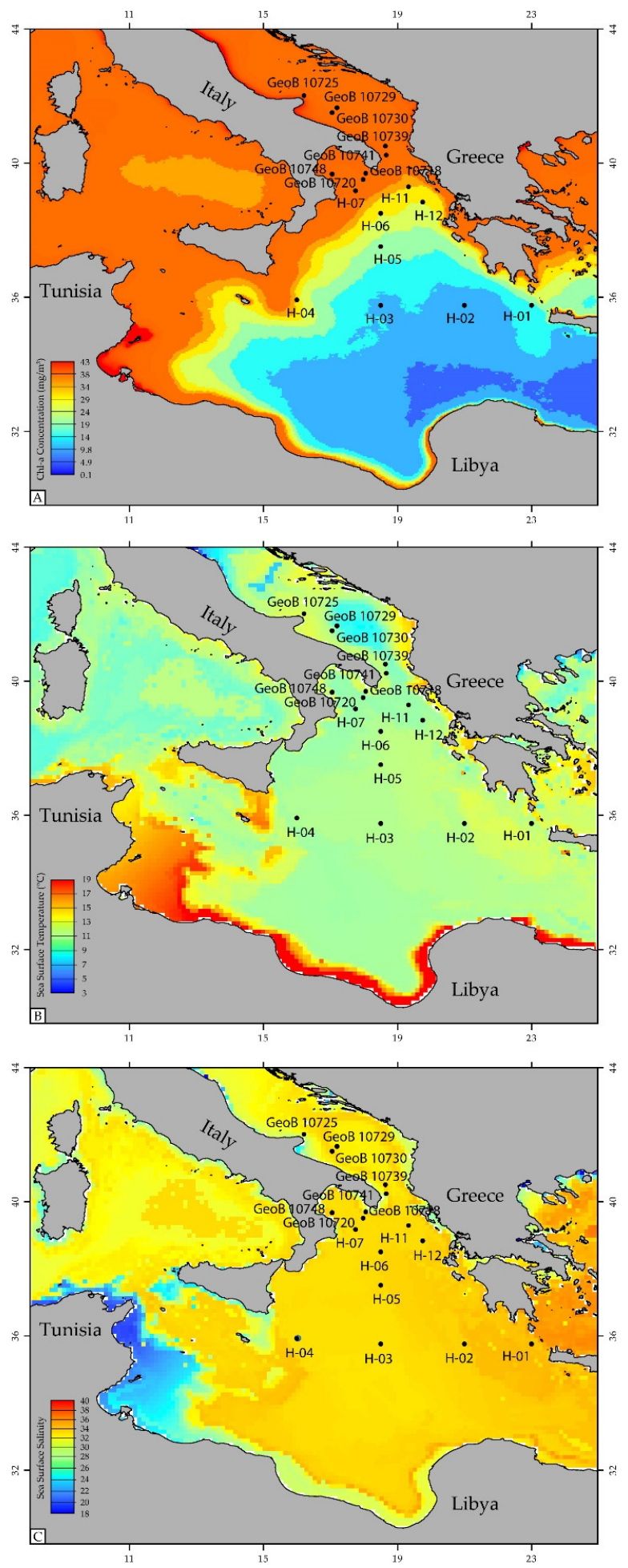

Figure 4. (A) Chlorophyll-a (Chl-a), (B) sea surface temperature (SST), and (C) sea surface salinity (SSS) distribution map for the study area. 
However, the additional factors of heterogeneous bathymetry and distance from the coast could not be omitted as they have a large influence on the distributional abundance pattern of this morphotype, as have already been indicated for the Adriatic [85] and the Aegean Sea [21]. Given the above factors, the observed distributional pattern of G. ruber s.l. could be correlated with a relevant trend to deeper habitats at these sites. As the nutrient content decreases offshore [77,119], this regime causes unfavorable conditions for this species, reflected by even more reduced percentages of the most productivity-sensitive morphotype Elongate (belonging to G. ruber s.l.). Consequently, the representatives of $G$. ruber s.l. are adapted to a different depth habitat, possibly beneath the halocline or deeper in the mixed layer to avoid the highly stratified and oligotrophic surface waters.

Besides the two abundant aforementioned species, most of the species that live in the central Mediterranean are surface/sub-surface symbiont bearing species (e.g., G. ruber rosea, G. rubescens, O. universa, G. siphonifera, T. trilobus) each one displaying percentages up to $\sim 10 \%$, while important components in some places are also the productivity- and stratification-related indicators, such as N. pachyderma, G. inflata, T. quinqueloba, and G. glutinata $[1,120]$. The significant cumulative percentage (up to $30 \%$ ) of symbiont-bearing species seems to reflect the ability of this group to cope with the oligotrophy of the study area. Particularly, G. ruber rosea and G. rubescens thrive in a warmer and overall, more oligotrophic and stratified water column $[28,103,121]$, and T. trilobus dwells in warm, oligotrophic to mesotrophic waters but prefers less salty superficial waters [95,122]. Orbulina universa is usually abundant in (sub)tropical to temperate waters and tolerates a wide range of salinity and temperature $[47,95]$. Its increased percentages in the Adriatic and Ionian sites could be interpreted as an increase in depth and possibly the extent of the thermocline. In only some locations (e.g., samples H-11, GeoB 10729), these species are replaced by asymbionts (e.g., T. quinqueloba, G. bulloides) and some deeper dwellers, mostly by N. pachyderma and G. inflata, that are associated with deep winter mixing and generally more productive environments $[22,95,123]$. The relatively low percentages of $G$. inflata and its general displacement from the Ionian to the Adriatic basin could be explained by the fact that this species is less frequent or absent in warmer, stratified, and nutrient-depleted regions of the Mediterranean than in more productive areas (e.g., western Mediterranean; [22,109]). The same applies to T. quinqueloba, which maintains a residual presence in the study area, since its ecological preferences are mostly linked to cold and very productive surface waters $[103,124]$. The cosmopolitan species G. glutinata comprises significant percentages up to $\sim 10 \%$ of the assemblage composition since it is able to survive both in oligotrophic and mesotrophic environments [125] due to its dual behavior related to diet requirements, being thus very sensitive to changes in productivity $[42,126]$, while it is not dependent on temperature, salinity or depth [1]. Its presence in the Mediterranean Sea has been attributed to the spring bloom, triggered by the increased nutrients at the end of the winter mixing and increased solar irradiation $[22,127]$.

\subsection{On the Environmental Component on the Latitudinal Size Variability}

The average maximum diameter $(282 \mu \mathrm{m})$ of the central Mediterranean (excluding the Tyrrhenian Sea) assemblages is comparable with that of the eastern Mediterranean (279 $\mu \mathrm{m}$; [24]), but slightly lower than that reported for subtropical assemblages on a global scale $(309 \mu \mathrm{m}$; [37]). The $\sim 8 \%$ offset in planktonic size could be considered reliable due to the more oligotrophic nature of higher water density in the marginal Mediterranean Sea compared to the global open ocean. Although tolerance limits of modern foraminifera are not completely defined, the progressive increase in test size is initially believed to be related to ecological optimum conditions [37,128-130]. Nevertheless, we note that the majority (apart from Schmidt et al. [37] who analyzed 69 Holocene samples worldwide) of the studies supports the optimum-size hypothesis focused on sediment samples collected within a single oceanic basin [31,131-135], reflecting a limited part of the biogeographical range of each species. 
Most shell-mass-related studies have shown that the planktonic foraminiferal shell size increase with seawater temperature (e.g., [38]). In the case of the central Mediterranean basin, the increase in sea surface temperature from the Adriatic to the southernmost Ionian sites (Figure 4) could partly explain the average 11\% increase observed in most of the species. However, this trend does not exist for the most dominant species, since both G. bulloides and G. ruber (w; s.s. and s.l.) present larger tests at higher latitudes. The decreasing trend with latitude of these two species is quite similar to that $(\sim 10 \%$ decrease towards the Levantine basin) reported by Zarkogiannis et al. [24] for the eastern sector of the Mediterranean Sea, indicating the latitudinal influence on these species within the entire Mediterranean Sea. This finding is also supplemented by the recent observations of Mallo et al. [81] showing a W-E difference in size of the same species (more extreme in G. ruber than G. bulloides, as similarly observed in our N-S transect), with the western basin hosting the largest individuals, while the gradual decrease in shell size occurs in the Tyrrhenian, eastern Ionian and finally in Levantine basin. Both latitudinal and longitudinal trends clearly reveal that the most abundant and paleoceanographically significant species for the Mediterranean Sea are possibly driven by environmental forces, beyond the SST, in terms of the specific hydrographic dynamics of each sub-basin within the Mediterranean Sea. Our findings are consistent with the observations of Rillo et al. [136] highlighting that SST does not always explain shell size variations, and further show that contrasting results can be obtained when analyzing intra-specific size patterns, even in a narrower geographical range as that one adopted here. Furthermore, given the species-specific size variability presented for the first time here, this study could be considered as a pioneer since it fills the gap characterized by the lack of studies testing the intraspecific consistency of the optimum-size hypothesis.

Nutrient availability can mediate the temperature-size relationships observed in the plankton communities and has been shown to affect planktonic foraminifera size [136,137]. More explicitly, enhanced food availability in the water column facilitates faster cell growth and larger final shell size [138,139]. On a global scale, surface primary productivity is strongly correlated with plankton size. Below the value of $150 \mathrm{~g} \mathrm{C} \mathrm{m}^{-2} \mathrm{yr}^{-1}$ there is a positive relationship, while above this threshold the cell size decreases with increasing primary productivity [37]. Within the low-productivity ecosystem of the Mediterranean Sea ( $<150 \mathrm{~g} \mathrm{C} \mathrm{m}^{-2} \mathrm{yr}^{-1}$; [140]) it would be expected shell size to be increased with productivity. According to the current and the already known from the literature's Mediterranean dataset, the above size-productivity relationship is evident for several species, mostly the symbiont-barren taxa, and is more pronounced in a longitudinal way. For instance, O. universa presents larger size fractions in the eutrophic upwelling areas from the Atlantic to the Strait of Sicily [89], relatively intermediate-sized shells in mesotrophic-to-oligotrophic Adriatic and Ionian basins (this study) and lowermost sizes into the ultra-oligotrophic eastern Mediterranean basin [24]. Into the general oligotrophic Adriatic and Ionian settings, G. ruber and other photosymbiotic species seem to have an advantage due to their symbionts which they use as an ecological strategy to survive in nutrient-limited environments [141]. The relatively stable shell sizes reported between Adriatic and Ionian domains of the most abundant species G. ruber s.s. (229 vs. $223 \mu \mathrm{m}$; Table 2) and G. bulloides (227 vs. $217 \mu \mathrm{m}$; Table 2) clearly support this concept. Moreover, the fact that these species were developed almost equally in size, presenting size structure values around roughly $220 \mu \mathrm{m}$, indicates that they possibly reach the optimum environmental conditions for the study area. The less abundant species (e.g., G. ruber s.l., G. ruber rosea, and G. rubescens), which are usually influenced by the competition with more abundant co-occurring species, present significant size variability and thereby reach their highest shell sizes in sub-optimal conditions. The comparison between the average intraspecific shell sizes for the central and the eastern basins (Table 3) points toward which species reaches the optimum or sub-optimum conditions and in which basin exactly within the Mediterranean setting. We nonetheless note that an additional N-S transect in the western Mediterranean, where the 
eutrophic species dominate, is needed to complete full geographic coverage of the shell differentiation into the entire Mediterranean Sea.

Table 3. Average population size of the identified planktonic foraminifera species within the Central Mediterranean (this study) and comparison with the Eastern Mediterranean basin [24]. The number of sampling locations that each species was encountered is also shown together with the total number of specimens counted. nd: not determined.

\begin{tabular}{|c|c|c|c|c|c|}
\hline \multirow[t]{2}{*}{ Species } & \multicolumn{2}{|c|}{$\mathrm{ECD}(\mu \mathrm{m})$} & \multirow[t]{2}{*}{ St. Dev. (\%) } & \multirow[t]{2}{*}{ No of Sites } & \multirow[t]{2}{*}{$\begin{array}{c}\text { No of } \\
\text { Specimens }\end{array}$} \\
\hline & $\begin{array}{c}\text { Central } \\
\text { Mediterranean }\end{array}$ & $\begin{array}{c}\text { Eastern } \\
\text { Mediterranean }\end{array}$ & & & \\
\hline Globigerinoides ruber s.s. & 224 & 218 & 8 & 17 & 897 \\
\hline Globigerinoides ruber s.l. & 279 & 259 & 11 & 17 & 592 \\
\hline Globigerinoides ruber rosea & 313 & 338 & 15 & 16 & 192 \\
\hline Trilobatus trilobus & 280 & 315 & 18 & 16 & 122 \\
\hline Globigerinella siphonifera & 292 & 305 & 15 & 17 & 260 \\
\hline Globigerina bulloides & 218 & 207 & 9 & 17 & 1463 \\
\hline Neogloboquadrina pachyderma & 227 & 220 & 14 & 12 & 211 \\
\hline Globorotalia inflata & 337 & 266 & 17 & 11 & 90 \\
\hline Globorotalia truncatulinoides & 435 & nd & 20 & 5 & 20 \\
\hline Globigerina rubescens & 184 & 189 & 11 & 13 & 140 \\
\hline Orbulina universa & 471 & 427 & 19 & 17 & 180 \\
\hline Turborotalita quinqueloba & 171 & 192 & 14 & 12 & 79 \\
\hline Globigerinita glutinata & 188 & 189 & 13 & 13 & 118 \\
\hline
\end{tabular}

\subsection{The Possible Role of a Hidden Biological Diversity in Mediterranean Assemblages}

Numerous studies have shown that many planktonic foraminiferal species display multiple genotypes, which are genetically independent but morphologically similar [142-144]. These cryptic species may also have different geographical distributions exhibiting possible morphological gradients with latitude [145] or longitude [107], occupy different niches [142], and display different relationships between abundance, size patterns, and environmental parameters [146-148]. Among the identified species, variable relationships have been discovered between their cryptic species and depth-, and/or environmental (SST, stratification, productivity)-related specializations whose abundance, shell size, and porosity vary with latitude. For instance, the size-abundance-environmental relationship has been documented for species with cryptic diversity, namely O. universa $[131,146,149-151]$, G. inflata [152], G. ruber [144,146,153], G. siphonifera [148,154,155], G. truncatulinoides [156,157], G. bulloides $[144,146,158,159]$ and N. pachyderma [160-164]. For most of them, both spinose and non-spinose species, it is premature to invoke cryptic diversity and ecophenotypy relationships due to the lack of large-scale inter-basin analysis within the Mediterranean Sea. However, some of them, especially those presenting the greatest variability in shell size ranges (G. truncatulinoides, G. inflata, and O. universa) could constitute good candidates for better explaining the observed geographic differentiation in the study area. Therefore, we interpret the documented latitudinal divergent trends among the fauna as the consequence of a hidden biological diversity with different mean sizes within these taxa, adapted to particular hydrographic conditions. We further note that there may be additional undiscovered genotypes in different lineages, especially in small and neglected species [165], possibly due to their relatively low number of specimens that have been surveyed so far. 


\subsection{Potential Depth Preferred Regulating Mechanism}

We did not find any relationship between population shell size and abundance, caution thus against the concept of intraspecific size variation in parallel with population abundances, in accordance with previous studies $[38,166]$. In the present study, species richness which previously has been positively correlated with assemblage size [37] is found constant along our transect, indicating that the population size variation cannot be explained by assemblage changes. The relatively constant number of 13 species identified in the majority of the studied core-top samples is by $\sim 40 \%$ lower than that of the low productivity oceanic gyre centers (>20 species; [167-169]), but similar to that of the marginal seas $[22,89,170]$. The slightly higher number in species richness reported here, compared to the number of 10 that characterizes the ultra-oligotrophic regions (e.g., Levantine Sea [20], Red Sea [171]), results mainly from the presence of cold- and deep-water dwellers that are associated with enhanced seasonal primary productivity $[109,172]$. The mechanism that could explain the expected ecological optimum pattern of simultaneous large sizes and high abundances involves higher feeding frequency (higher nutrient availability) leading to higher individual growth and finally to higher population growth [130]. However, it also implies that populations in different productive regimes have different generation times, with the more generations at optimum conditions to lead in higher abundance in the sediment, but relative to other populations of the same species, and not relative to the local assemblage [136]. In the local basin-wide abundance, nutrient availability is the same for all co-occurring species. Both satellite and in situ productivity data measured across the central Mediterranean reveal an increasing N-S oligotrophy gradient, mainly due to the limiting Chl-a concentrations from the Adriatic to Ionian Sea [115]. As would be expected, it is not followed by a relevant decrease in abundance for several species (e.g., G. ruber, G. siphonifera, G. glutinata), which means that the above mechanism cannot be applied here, since the primary production pattern of the region cannot explain sufficiently the observed decrease in mean foraminiferal size with latitude for the most abundant species either the opposite trend for the rest of the species in accordance also with their abundances. To understand the observed trends, we need to consider the effects of vertical instability on planktonic assemblages. The mesotrophic to oligotrophic character of the central Mediterranean basin is reflected by surface-dwelling oligotrophic and deeper eutrophic faunas, both of which are growing outside their ecologically optimum ranges (eastern and western Mediterranean respectively). In this setting, the overall assemblage is thus characterized by many species with almost overlapping shell sizes (Table 2). The species with a constant depth habitat such as G. ruber s.s, T. quinqueloba, and T. trilobus obviously are within optimal conditions and therefore present the lowest size variability. On the contrary, the species presenting a more variable depth habitat (e.g., G. bulloides, G. ruber s.l., O. universa) in their attempt to find plentiful food should be adapted to greater depths, representing sub-optimal ecological conditions for their survival.

\section{Conclusions}

In the present work, we studied the abundance and size distribution of recent planktonic foraminiferal populations derived by 17 surface sediment samples spanning from the mesotrophic Adriatic to the oligotrophic Ionian Sea. The fauna consists of subtropical species, mostly symbiont-bearing spinose species indicative of the mesotrophic-tooligotrophic nature of the study area. Even though the most abundant species G. bulloides and G. ruber (w) show an antagonistic distributional pattern, both present the opposite trend compared to the rest of the species with their average size decreasing with latitude. The recent fluctuations in the relative abundance along with morphospecies-specific shell size trends of the dominating species may reflect the current adjustment to ongoing sea surface warming and a decrease in primary productivity in certain depth levels along the N-S transect. Overall, our findings are consistent with previous studies, which suggest that sea surface temperature, depth habitat, and food availability are the main controlling factors for their latitudinal distributional differentiation in the central Mediterranean. Moreover, shell 
size variation in planktonic foraminiferal species analyzed cannot be consistently predicted by the environment, with a hidden biological diversity with different mean sizes within these taxa to be possibly appeared, as an adaptation to ecological (sub)optimum conditions.

Author Contributions: Conceptualization, G.K., S.D.Z.; methodology, G.K., S.D.Z.; software, G.K., S.D.Z., E.E.; validation, G.K., S.D.Z., E.E.; formal analysis, G.K., S.D.Z., E.E.; investigation, G.K., S.D.Z., E.E., E.B., A.A.; resources, G.K.; data curation, G.K., S.D.Z., E.E., A.A.; writing-Original draft preparation, G.K.; writing-Review and editing, G.K., S.D.Z., E.E., E.B., A.A.; visualization, G.K., S.D.Z.; supervision, A.A.; project administration, G.K., A.A.; funding acquisition, G.K. All authors have read and agreed to the published version of the manuscript.

Funding: This research received no external funding.

Institutional Review Board Statement: Not applicable.

Informed Consent Statement: Not applicable.

Data Availability Statement: Data that support the findings of this study are available from the corresponding author upon reasonable request.

Acknowledgments: The authors are grateful to Jurgen Möbius for providing part of the study material. The constructive and thorough reviews of two anonymous reviewers are warmly acknowledged.

Conflicts of Interest: The authors declare no conflict of interest.

\section{References}

1. Hemleben, C.; Anderson, O.R.; Spindler, M. Modern Planktonic Foraminifera; Springer: New York, NY, USA, 1989.

2. Tsiolakis, E.; Tsaila-Monopoli, S.; Kontakiotis, G.; Antonarakou, A.; Sprovieri, M.; Geraga, M.; Ferentinos, G.; Zissimos, A. Integrated paleohydrology reconstruction and Pliocene climate variability in Cyprus Island (eastern Mediterranean). Iop Conf. Ser. Earth Environ. Sci. 2019, 362, 012103. [CrossRef]

3. Antonarakou, A.; Kontakiotis, G.; Karageorgis, A.P.; Besiou, E.; Zarkogiannis, S.; Drinia, H.; Mortyn, G.P.; Tripsanas, E. Ecobiostratigraphic advances on late Quaternary geochronology and palaeoclimate: The marginal Gulf of Mexico analogue. Geol. Q. 2019, 63, 178-191. [CrossRef]

4. Budillon, F.; Lirer, F.; Iorio, M.; Macrì, P.; Sagnotti, L.; Vallefuoco, M.; Ferraro, L.; Garziglia, S.; Innangi, S.; Sahabi, M.; et al. Integrated stratigraphic reconstruction for the last $80 \mathrm{kyr}$ in a deep sector of the Sardinia Channel (Western Mediterranean). Deep Sea Res. II 2009, 56, 725-737. [CrossRef]

5. Drinia, H.; Antonarakou, A.; Tsourou, T.; Kontakiotis, G.; Psychogiou, M.; Anastasakis, G. Foraminifera eco-biostratigraphy of the southern Evoikos outer shelf, central Aegean Sea, during MIS 5 to present. Cont. Shelf Res. 2016, 126, 36-49. [CrossRef]

6. Lirer, F.; Luca, M.; Iaccarino, S.; Gianfranco, S.; Turco, E.; Claudia, C.; Sierro, F.; Caruso, A. Mediterranean Neogene planktonic foraminifer biozonation and biochronology. Earth-Sci. Rev. 2019, 196. [CrossRef]

7. Triantaphyllou, M.V.; Antonarakou, A.; Kouli, K.; Dimiza, M.; Kontakiotis, G.; Papanikolaou, M.D.; Ziveri, P.; Mortyn, P.G.; Lianou, V.; Lykousis, V.; et al. Late Glacial-Holocene ecostratigraphy of the south-eastern Aegean Sea, based on plankton and pollen assemblages. Geo-Mar. Lett. 2009, 29, 249-267. [CrossRef]

8. Giamali, C.; Kontakiotis, G.; Koskeridou, E.; Ioakim, C.; Antonarakou, A. Key Environmental Factors Controlling Planktonic Foraminiferal and Pteropod Community's Response to Late Quaternary Hydroclimate Changes in the South Aegean Sea (Eastern Mediterranean). J. Mar. Sci. Eng. 2020, 8, 709. [CrossRef]

9. Giamali, C.; Koskeridou, E.; Antonarakou, A.; Kontakiotis, G.; Ioakim, C.; Karageorgis, A.; Roussakis, G.; Karakitsios, V. Multiproxy marine ecosystem response of abrupt Holocene climatic changes in the northeastern Mediterranean sedimentary archive. Quat. Res. 2019, 92, 665-685. [CrossRef]

10. Kontakiotis, G.; Besiou, E.; Antonarakou, A.; Zarkogiannis, S.D.; Kostis, A.; Mortyn, P.G.; Moissette, P.; Cornée, J.J.; Schulbert, C.; Drinia, H.; et al. Decoding sea surface and paleoclimate conditions in the eastern Mediterranean over the Tortonian-Messinian Transition. Palaeogeogr. Palaeoclimatol. Palaeoecol. 2019, 534, 109312. [CrossRef]

11. Kontakiotis, G.; Karakitsios, V.; Mortyn, P.G.; Antonarakou, A.; Drinia, H.; Anastasakis, G.; Agiadi, K.; Kafousia, N.; De Rafelis, M. New insights into the early Pliocene hydrographic dynamics and their relationship to the climatic evolution of the Mediterranean Sea. Palaeogeogr. Palaeoclimatol. Palaeoecol. 2016, 459, 348-364. [CrossRef]

12. Le Houedec, S.; Mojtahid, M.; Bicchi, E.; de Lange, G.J.; Hennekam, R. Suborbital Hydrological Variability Inferred From Coupled Benthic and Planktic Foraminiferal-Based Proxies in the Southeastern Mediterranean During the Last 19 ka. Paleoceanogr. Paleoclimatol. 2020, 35, e2019PA003827. [CrossRef]

13. Louvari, M.A.; Drinia, H.; Kontakiotis, G.; Di Bella, L.; Antonarakou, A.; Anastasakis, G. Impact of latest-glacial to Holocene sea-level oscillations on central Aegean shelf ecosystems: A benthic foraminiferal palaeoenvironmental assessment of South Evoikos Gulf, Greece. J. Mar. Syst. 2019. [CrossRef] 
14. Margaritelli, G.; Cacho, I.; Català, A.; Barra, M.; Bellucci, L.G.; Lubritto, C.; Rettori, R.; Lirer, F. Persistent warm Mediterranean surface waters during the Roman period. Sci. Rep. 2020, 10, 10431. [CrossRef]

15. Margaritelli, G.; Vallefuoco, M.; Di Rita, F.; Capotondi, L.; Bellucci, L.G.; Insinga, D.D.; Petrosino, P.; Bonomo, S.; Cacho, I.; Cascella, A.; et al. Marine response to climate changes during the last five millennia in the central Mediterranean Sea. Glob. Planet. Chang. 2016, 142, 53-72. [CrossRef]

16. Quillévéré, F.; Nouailhat, N.; Joannin, S.; Cornée, J.-J.; Moissette, P.; Lécuyer, C.; Fourel, F.; Agiadi, K.; Koskeridou, E.; Escarguel, G. An onshore bathyal record of tectonics and climate cycles at the onset of the Early-Middle Pleistocene Transition in the eastern Mediterranean. Quat. Sci. Rev. 2019, 209, 23-39. [CrossRef]

17. Siani, G.; Paterne, M.; Colin, C. Late glacial to Holocene planktic foraminifera bioevents and climatic record in the South Adriatic Sea. J. Quat. Sci. 2010, 25, 808-821. [CrossRef]

18. Kontakiotis, G.; Mortyn, P.G.; Antonarakou, A.; Martínez-Botí, M.A.; Triantaphyllou, M.V. Field-based validation of a diagenetic effect on G. ruber Mg/Ca paleothermometry: Core top results from the Aegean Sea (eastern Mediterranean). Geochem. Geophys. Geosyst. 2011, 12, Q09004. [CrossRef]

19. Vasiliev, I.; Karakitsios, V.; Bouloubassi, I.; Agiadi, K.; Kontakiotis, G.; Antonarakou, A.; Triantaphyllou, M.; Gogou, A.; Kafousia, N.; de Rafélis, M.; et al. Large Sea Surface Temperature, Salinity, and Productivity-Preservation Changes Preceding the Onset of the Messinian Salinity Crisis in the Eastern Mediterranean Sea. Paleoceanogr. Paleoclimatol. 2019, 34, 182-202. [CrossRef]

20. Avnaim-Katav, S.; Herut, B.; Rahav, E.; Katz, T.; Weinstein, Y.; Alkalay, R.; Berman-Frank, I.; Zlatkin, O.; Almogi-Labin, A. Sediment trap and deep sea coretop sediments as tracers of recent changes in planktonic foraminifera assemblages in the southeastern ultra-oligotrophic Levantine Basin. Deep Sea Res. Part II Top. Stud. Oceanogr. 2020, 171, 104669. [CrossRef]

21. Kontakiotis, G.; Antonarakou, A.; Mortyn, P.G.; Drinia, H.; Anastasakis, G.; Zarkogiannis, S.; Möbius, J. Morphological recognition of Globigerinoides ruber morphotypes and their susceptibility to diagenetic alteration in the eastern Mediterranean Sea. J. Mar. Syst. 2017, 174, 12-24. [CrossRef]

22. Pujol, C.; Grazzini, C.V. Distribution patterns of live planktic foraminifers as related to regional hydrography and productive systems of the Mediterranean Sea. Mar. Micropaleontol. 1995, 25, 187-217. [CrossRef]

23. Wilson, B. Biogeography and ecostratigraphy of Late Quaternary planktonic foraminiferal taphocoenoses in the Leeward Islands, Lesser Antilles, NE Caribbean Sea. Mar. Micropaleontol. 2012, 86-87, 1-10. [CrossRef]

24. Zarkogiannis, S.; Kontakiotis, G.; Antonarakou, A. Recent planktonic foraminifera population and size response to Eastern Mediterranean hudrography. Rev. Micropaleontol. 2020, 69, 100450. [CrossRef]

25. Bé, A.W.H.; Tolderlund, D.S. Distribution and ecology of living planktonic foraminifera in surface waters of the Atlantic and Indian Oceans. In The Micropaleontology of Oceans; Funnel, B.M., Riedel, W.R., Eds.; Cambridge University Press: Cambridge, UK, 1971; pp. 105-149.

26. Kucera, M. Chapter Six Planktonic Foraminifera as Tracers of Past Oceanic Environments. In Developments in Marine Geology; Hillaire-Marcel, C., De Vernal, A., Eds.; Elsevier: Amsterdam, The Netherlands, 2007; Volume 1, pp. $213-262$.

27. Imbrie, J.; Kipp, N. A new micropaleontological method for quantitative paleoclimatology: Application to a late pleistocene Caribbean core. In The Late Cenozoic Glacial Ages; Turekian, K.K., Ed.; Yale University Press: New Haven, CT, USA, 1971; pp. 71-181.

28. Kontakiotis, G. Late Quaternary paleoenvironmental reconstruction and paleoclimatic implications of the Aegean Sea (eastern Mediterranean) based on paleoceanographic indexes and stable isotopes. Quat. Int. 2016, 401, 28-42. [CrossRef]

29. Kucera, M.; Weinelt, M.; Kiefer, T.; Pflaumann, U.; Hayes, A.; Weinelt, M.; Chen, M.-T.; Mix, A.C.; Barrows, T.T.; Cortijo, E.; et al. Reconstruction of sea-surface temperatures from assemblages of planktonic foraminifera: Multi-technique approach based on geographically constrained calibration data sets and its application to glacial Atlantic and Pacific Oceans. Quat. Sci. Rev. 2005, 24, 951-998. [CrossRef]

30. Berger, W.H. Kummerform foraminifera as clues to Oceanic environments: Abstract. Am. Assoc. Pet. Geol. Bull. 1969, 53. [CrossRef]

31. Moller, T.; Schulz, H.; Kucera, M. The effect of sea surface properties on shell morphology and size of the planktonic foraminifer Neogloboquadrina pachyderma in the North Atlantic. Palaeogeogr. Palaeoclimatol. Palaeoecol. 2013, 391, 34-48. [CrossRef]

32. Morey, A.; Mix, A.; Pisias, N. Planktonic foraminiferal assemblages preserved in surface sediments correspond to multiple environment variables. Quat. Sci. Rev. 2005, 24, 925-950. [CrossRef]

33. Ortiz, J.D.; Mix, A.C.; Collier, R.W. Environmental control of living symbiotic and asymbiotic foraminifera of the California Current. Paleoceanography 1995, 10, 987-1009. [CrossRef]

34. Rebotim, A.; Voelker, A.H.L.; Jonkers, L.; Waniek, J.J.; Meggers, H.; Schiebel, R.; Fraile, I.; Schulz, M.; Kucera, M. Factors controlling the depth habitat of planktonic foraminifera in the subtropical eastern North Atlantic. Biogeosci. Discuss. 2016, 2016, 1-48. [CrossRef]

35. Renaud, S.; Schmidt, D. Habitat tracking as a response of the planktic foraminifer Globorotalia truncatulinoides to environmental fluctuations during the last 140 kyr. Mar. Micropaleontol. 2003, 49, 97-122. [CrossRef]

36. Schiebel, R.; Waniek, J.; Bork, M.; Hemleben, C. Planktic foraminiferal production stimulated by chlorophyll redistribution and entrainment of nutrients. Deep Sea Res. Part I Oceanogr. Res. Pap. 2001, 48, 721-740. [CrossRef]

37. Schmidt, D.N.; Renaud, S.; Bollmann, J.; Schiebel, R.; Thierstein, H.R. Size distribution of Holocene planktic foraminifer assemblages: Biogeography, ecology and adaptation. Mar. Micropaleontol. 2004, 50, 319-338. [CrossRef] 
38. Weinkauf, M.F.G.; Kunze, J.G.; Waniek, J.J.; Kučera, M. Seasonal variation in shell calcification of planktonic foraminifera in the NE Atlantic reveals species-specific response to temperature, productivity, and optimum growth conditions. PLOS ONE 2016, 11, e0148363. [CrossRef] [PubMed]

39. Siokou-Frangou, I.; Bianchi, M.; Christaki, U.; Christou, E.D.; Giannakourou, A.; Gotsis, O.; Ignatiades, L.; Pagou, K.; Pitta, P.; Psarra, S.; et al. Carbon flow in the planktonic food web along a gradient of oligotrophy in the Aegean Sea (Mediterranean Sea). J. Mar. Syst. 2002, 33-34, 335-353. [CrossRef]

40. Siokou-Frangou, I.; Christaki, U.; Mazzocchi, M.G.; Montresor, M.; Ribera d'Alcalá, M.; Vaqué, D.; Zingone, A. Plankton in the open Mediterranean Sea: A review. Biogeosciences 2010, 7, 1543-1586. [CrossRef]

41. Wassmann, P.; Ypma, J.E.; Tselepides, A. Vertical flux of faecal pellets and microplankton on the shelf of the oligotrophic Cretan Sea (NE Mediterranean Sea). Prog. Oceanogr. 2000, 46, 241-258. [CrossRef]

42. Schmuker, B.; Schiebel, R. Planktic foraminifers and hydrography of the eastern and northern Caribbean Sea. Mar. Micropaleontol. 2002, 46, 387-403. [CrossRef]

43. Lykousis, V.; Chronis, G.; Tselepides, A.; Price, N.B.; Theocharis, A.; Siokou-Frangou, I.; Van Wambeke, F.; Danovaro, R.; Stavrakakis, S.; Duineveld, G.; et al. Major outputs of the recent multidisciplinary biogeochemical researches undertaken in the Aegean Sea. J. Mar. Syst. 2002, 33-34, 313-334. [CrossRef]

44. Schiebel, R. Planktic foraminiferal sedimentation and the marine calcite budget. Glob. Biogeochem. Cycles 2002, 16, 1065. [CrossRef]

45. Schiebel, R.; Hemleben, C. Modern planktic foraminifera. Palaontol. Z. 2005, 79, 135-148. [CrossRef]

46. Siccha, M.; Schiebel, R.; Schmidt, S.; Howa, H. Short-term and small-scale variability in planktic foraminifera test flux in the Bay of Biscay. Deep Sea Res. Part I Oceanogr. Res. Pap. 2012, 64, 146-156. [CrossRef]

47. Bijma, J.; Faber, W.W.; Hemleben, C. Temperature and salinity limits for growth and survival of some planktonic foraminifers in laboratory cultures. J. Foraminifer. Res. 1990, 20, 95-116. [CrossRef]

48. Arnold, A.J.; Parker, W.C. Biogeography of Planktonic Foraminifera; Springer: Dortrecht, The Netherlands; Boston, MA, USA; London, UK, 1999.

49. Zarkogiannis, S.; Kontakiotis, G.; Antonarakou, A.; Mortyn, P.; Drinia, H. Latitudinal Variation of Planktonic Foraminifera Shell Masses During Termination I. Iop Conf. Ser. Earth Environ. Sci. 2019, 221, 012052. [CrossRef]

50. Zarkogiannis, S.D.; Antonarakou, A.; Tripati, A.; Kontakiotis, G.; Mortyn, P.G.; Drinia, H.; Greaves, M. Influence of surface ocean density on planktonic foraminifera calcification. Sci. Rep. 2019, 9, 533. [CrossRef]

51. Caromel, A.G.M.; Schmidt, D.N.; Phillips, J.C.; Rayfield, E.J. Hydrodynamic constraints on the evolution and ecology of planktic foraminifera. Mar. Micropaleontol. 2014, 106, 69-78. [CrossRef]

52. Caromel, A.G.M.; Schmidt, D.N.; Rayfield, E.J. Ontogenetic constraints on foraminiferal test construction. Evol. Dev. 2017, 19, 157-168. [CrossRef]

53. Zarkogiannis, S.; Kontakiotis, G.; Antonarakou, A. Logarithmic expression of Globigerina bulloides shell evolution through the biometric analysis: Paleoceanographic implications for the late Quaternary. Iop Conf. Ser. Earth Environ. Sci. 2019, $362,012100$. [CrossRef]

54. Robinson, A.R.; Golnaraghi, M. The Physical and Dynamical Oceanography of the Mediterranean Sea. In Ocean Processes in Climate Dynamics: Global and Mediterranean Examples; Malanotte-Rizzoli, P., Robinson, A.R., Eds.; Springer: Dordrecht, The Netherlands, 1994; pp. 255-306.

55. Cushman-Roisin, B.; Gacic, M.; Poulain, P.-M.; Artegiani, A. Physical Oceanography of the Adriatic Sea: Past, Present and Future; Springer: Dordrecht, The Netherlands, 2001.

56. Ricci, P.; Libralato, S.; Capezzuto, F.; D’Onghia, G.; Maiorano, P.; Sion, L.; Tursi, A.; Solidoro, C.; Carlucci, R. Ecosystem functioning of two marine food webs in the North-Western Ionian Sea (Central Mediterranean Sea). Ecol. Evol. 2019, 9, 10198-10212. [CrossRef]

57. Civitarese, G.; Gacic, M.; Lipizer, M.; Eusebi Borzelli, G.L. On the impact of the Bimodal Oscillating System (BiOS) on the biogeochemistry and biology of the Adriatic and Ionian Seas (Eastern Mediterranean). Biogeosciences 2010, 7, $3987-3997$. [CrossRef]

58. Specchiulli, A.; Bignami, F.; Marini, M.; Fabbrocini, A.; Scirocco, T.; Campanelli, A.; Penna, P.; Santucci, A.; D’ Adamo, R. The role of forcing agents on biogeochemical variability along the southwestern Adriatic coast: The Gulf of Manfredonia case study. Estuar. Coast. Shelf Sci. 2016, 183, 136-149. [CrossRef]

59. Béranger, K.; Mortier, L.; Crépon, M. Seasonal variability of water transport through the Straits of Gibraltar, Sicily and Corsica, derived from a high-resolution model of the Mediterranean circulation. Prog. Oceanogr. 2005, 66, 341-364. [CrossRef]

60. Pinardi, N.; Masetti, E. Variability of the large scale general circulation of the Mediterranean Sea from observations and modelling: A review. Palaeogeogr. Palaeoclimatol. Palaeoecol. 2000, 158, 153-173. [CrossRef]

61. Robinson, A.R.; Sellschopp, J.; Warn-Varnas, A.; Leslie, W.G.; Lozano, C.J.; Haley, P.J.; Anderson, L.A.; Lermusiaux, P.F.J. The Atlantic Ionian Stream. J. Mar. Syst. 1999, 20, 129-156. [CrossRef]

62. Bonanno, A.; Placenti, F.; Basilone, G.; Mifsud, R.; Genovese, S.; Patti, B.; Di Bitetto, M.; Aronica, S.; Barra, M.; Giacalone, G.; et al. Variability of water mass properties in the Strait of Sicily in summer period of 1998-2013. Ocean Sci. Discuss. 2014, 11. [CrossRef]

63. Sammari, C.; Millot, C.; Taupier-Letage, I.; Stefani, A.; Brahim, M. Hydrological characteristics in the Tunisia-Sardinia-Sicily area during spring 1995. Deep Sea Res. Part I Oceanogr. Res. Pap. 1999, 46, 1671-1703. [CrossRef] 
64. Gačić, M.; Schroeder, K.; Civitarese, G.; Cosoli, S.; Vetrano, A.; Eusebi Borzelli, G.L. Salinity in the Sicily Channel corroborates the role of the Adriatic-Ionian Bimodal Oscillating System (BiOS) in shaping the decadal variability of the Mediterranean overturning circulation. Ocean Sci. 2013, 9, 83-90. [CrossRef]

65. Pinardi, N.; Zavatarelli, M.; Adani, M.; Coppini, G.; Fratianni, C.; Oddo, P.; Simoncelli, S.; Tonani, M.; Lyubartsev, V.; Dobricic, S.; et al. Mediterranean Sea large-scale low-frequency ocean variability and water mass formation rates from 1987 to 2007: A retrospective analysis. Prog. Oceanogr. 2015, 132, 318-332. [CrossRef]

66. Roether, W.; Manca, B.B.; Klein, B.; Bregant, D.; Georgopoulos, D.; Beitzel, V.; Kovačević, V.; Luchetta, A. Recent Changes in Eastern Mediterranean Deep Waters. Science 1996, 271, 333. [CrossRef]

67. Gasparini, G.P.; Ortona, A.; Budillon, G.; Astraldi, M.; Sansone, E. The effect of the Eastern Mediterranean Transient on the hydrographic characteristics in the Strait of Sicily and in the Tyrrhenian Sea. Deep Sea Res. Part I Oceanogr. Res. Pap. 2005, 52, 915-935. [CrossRef]

68. Marini, M.; Grilli, F.; Guarnieri, A.; Jones, B.; Klajic, Z.; Nadia, P.; Sanxhaku, M. Is the southeastern Adriatic Sea coastal strip an eutrophic area? Estuar. Coast. Shelf Sci. 2010, 395-406. [CrossRef]

69. Artegiani, A.; Paschini, E.; Russo, A.; Bregant, D.; Raicich, F.; Pinardi, N. The Adriatic Sea General Circulation. Part II: Baroclinic Circulation Structure. J. Phys. Oceanogr. 1997, 27, 1515-1532. [CrossRef]

70. Marini, M.; Jones, B.H.; Campanelli, A.; Grilli, F.; Lee, C.M. Seasonal variability and Po River plume influence on biochemical properties along western Adriatic coast. J. Geophys. Res. Ocean. 2008, 113. [CrossRef]

71. Orlic, M.; Dadic, V.; Grbec, B.; Leder, N.; Marki, A.; Matić, F.; Mihanovic, H.; Beg Paklar, G.; Pasaric, M.; Pasarić, Z.; et al. Wintertime buoyancy forcing, changing seawater properties, and two different circulation systems produced in the Adriatic. J. Geophys. Res. 2006, 112. [CrossRef]

72. Giani, M.; Djakovac, T.; Degobbis, D.; Cozzi, S.; Solidoro, C.; Umani, S.F. Recent changes in the marine ecosystems of the northern Adriatic Sea. Estuar. Coast. Shelf Sci. 2012, 115, 1-13. [CrossRef]

73. Manca, B.; Budillon, G.; Scarazzato, P.; Ursella, L. Evolution of dynamics in the eastern Mediterranean affecting water mass structures and properties in the Ionian and Adriatic Seas. J. Geophys. Res. 2003, 108. [CrossRef]

74. Degobbis, D.; Precali, R.; Ivančić, I.; Smodlaka, N.; Fuks, D.; Kveder, S. Long-term Changes in the northern Adriatic ecosystem related to anthropogenic eutrophication. Int. J. Environ. Pollut. 2000, 13, 495-533. [CrossRef]

75. Viličič, D.; Vučak, Z.; Škrivanić, A.; Grzetić, Z. Phytoplankton blooms in the oligotrophic open South Adriatic waters. Mar. Chem. 1989, 28, 89-107. [CrossRef]

76. Totti, C.; Civitarese, G.; Acri, F.; Barletta, D.; Candelari, G.; Paschini, E.; Solazzi, A. Seasonal variability of phytoplankton populations in the middle Adriatic sub-basin. J. Plankton Res. 2000, 22, 1735-1756. [CrossRef]

77. Zonneveld, K.; Chen, L.; Moebius, J.; Mahmoud, M. Environmental significance of dinoflagellate cysts from the proximal part of the Po-river discharge plume (off southern Italy, Eastern Mediterranean). J. Sea Res. 2009, 62, 189-213. [CrossRef]

78. Marasović, I.; Grbec, B.; Morović, M. Long-term production changes in the adriatic. Neth. J. Sea Res. 1995, 34, 267-273. [CrossRef]

79. Vilibić, I.; Šantić, D. Deep water ventilation traced by Synechococcus cyanobacteria. Ocean Dyn. 2008, 58, 119-125. [CrossRef]

80. Vilibić, I.; Matijevic, S.; Šepić, J.; Kušpilić, G. Changes in the Adriatic oceanographic properties induced by the Eastern Mediterranean Transient. Biogeosciences 2012, 9, 2085-2097. [CrossRef]

81. Palinkas, C.M.; Nittrouer, C.A. Clinoform sedimentation along the Apennine shelf, Adriatic Sea. Mar. Geol. 2006, 234, 245-260. [CrossRef]

82. Boudena, M. Sea Surface Temperature of the Central Mediterranean during the Last Millenium. Ph.D. Thesis, Università degli Studi di Torino, Turin, Italy, 2004; p. 64.

83. Frignani, M.; Langone, L.; Ravaioli, M.; Sorgente, D.; Alvisi, F.; Albertazzi, S. Fine-sediment mass balance in the western Adriatic continental shelf over a century time scale. Mar. Geol. 2005, 222-223, 113-133. [CrossRef]

84. Incarbona, A.; Ziveri, P.; Di Stefano, E.; Lirer, F.; Mortyn, G.; Patti, B.; Pelosi, N.; Sprovieri, M.; Tranchida, G.; Vallefuoco, M.; et al. The Impact of the Little Ice Age on Coccolithophores in the Central Mediterranea Sea. Clim. Past 2010, 6, 795-805. [CrossRef]

85. Grauel, A.L.; Bernasconi, S.M. Core-top calibration of $\delta^{18} \mathrm{O}$ and $\delta^{13} \mathrm{C}$ of G. ruber (white) and U. mediterranea along the southern Adriatic coast of Italy. Mar. Micropaleontol. 2010, 77, 175-186. [CrossRef]

86. Thunell, R.C. Distribution of recent planktonic foraminifera in surface sediments of the Mediterranean Sea. Mar. Micropaleontol. 1978, 3, 147-173. [CrossRef]

87. Zarkogiannis, S.D.; Kontakiotis, G.; Gkaniatsa, G.; Kuppili, V.S.C.; Marathe, S.; Wanelik, K.; Lianou, V.; Besiou, E.; Makri, P.; Antonarakou, A. An Improved Cleaning Protocol for Foraminiferal Calcite from Unconsolidated Core Sediments: HyPerCal-A New Practice for Micropaleontological and Paleoclimatic Proxies. J. Mar. Sci. Eng. 2020, 8, 998. [CrossRef]

88. Incarbona, A.; Stefano, E.; Sprovieri, R.; Ferraro, S. The Uniqueness of Planktonic Ecosystems in the Mediterranean Sea: The Response to Orbital- and Suborbital-Climatic Forcing over the Last 130,000 Years. Open Geosci. 2016, 8. [CrossRef]

89. Mallo, M.; Ziveri, P.; Mortyn, P.G.; Schiebel, R.; Grelaud, M. Low planktic foraminiferal diversity and abundance observed in a spring 2013 west-east Mediterranean Sea plankton tow transect. Biogeosciences 2017, 14, 2245-2266. [CrossRef]

90. Al-Sabouni, N.; Kucera, M.; Schmidt, D.N. Vertical niche separation control of diversity and size disparity in planktonic foraminifera. Mar. Micropaleontol. 2007, 63, 75-90. [CrossRef] 
91. Antonarakou, A.; Kontakiotis, G.; Zarkogiannis, S.; Mortyn, P.G.; Drinia, H.; Koskeridou, E.; Anastasakis, G. Planktonic foraminiferal abnormalities in coastal and open marine eastern Mediterranean environments: A natural stress monitoring approach in recent and early Holocene marine systems. J. Mar. Syst. 2018, 181, 63-78. [CrossRef]

92. Capotondi, L.; Erica, S.; Speranza, P.; Corselli, C. Late Quaternary planktonic foraminiferal distributions: Problems related to size fraction. In Proceedings of the First Italian Meeting on Environmental Micropaleontology Edition; Coccioni, R., Galeotti, S., Lirer, F., Eds.; Grzybowski Foundation Special Publication: Krakow, Poland, 2004; Volume 9, pp. 1-6.

93. Cisneros, M.; Cacho, I.; Frigola, J.; Canals, M.; Masqué, P.; Martrat, B.; Casado, M.; Grimalt, J.O.; Pena, L.D.; Margaritelli, G.; et al. Sea surface temperature variability in the central-western Mediterranean Sea during the last 2700 years: A multi-proxy and multi-record approach. Clim. Past 2016, 12, 849-869. [CrossRef]

94. Margaritelli, G.; Cisneros, M.; Cacho, I.; Capotondi, L.; Vallefuoco, M.; Rettori, R.; Lirer, F. Climatic variability over the last 3000 years in the central- western Mediterranean Sea (Menorca Basin) detected by planktonic foraminifera and stable isotope records. Glob. Planet. Chang. 2018, 169, 179-187. [CrossRef]

95. Schiebel, R.; Hemleben, C. Planktic Foraminifers in the Modern Ocean; Springer: Berlin/Heidelberg, Germany, 2017 ; p. 358.

96. Aurahs, R.; Grimm, G.W.; Hemleben, V.; Hemleben, C.; Kucera, M. Geographical distribution of cryptic genetic types in the planktonic foraminifer Globigerinoides ruber. Mol. Ecol. 2009, 18, 1692-1706. [CrossRef]

97. Wang, L. Isotopic signals in two morphotypes of Globigerinoides ruber (white) from the South China Sea: Implications for monsoon climate change during the last glacial cycle. Palaeogeogr. Palaeoclimatol. Palaeoecol. 2000, 161, 381-394. [CrossRef]

98. Kuroyanagi, A.; Kawahata, H. Vertical distribution of living planktonic foraminifera in the seas around Japan. Mar. Micropaleontol. 2004, 53, 173-196. [CrossRef]

99. Antonarakou, A.; Kontakiotis, G.; Mortyn, P.G.; Drinia, H.; Sprovieri, M.; Besiou, E.; Tripsanas, E. Biotic and geochemical $\left(\delta^{18} \mathrm{O}, \delta^{13} \mathrm{C}, \mathrm{Mg} / \mathrm{Ca}, \mathrm{Ba} / \mathrm{Ca}\right)$ responses of Globigerinoides ruber morphotypes to upper water column variations during the last deglaciation, Gulf of Mexico. Geochim. Cosmochim. Acta 2015, 170. [CrossRef]

100. Kuroyanagi, A.; Tsuchiya, M.; Kawahata, H.; Kitazato, H. The occurrence of two genotypes of the planktonic foraminifer Globigerinoides ruber (white) and paleo-environmental implications. Mar. Micropaleontol. 2008, 68, 236-243. [CrossRef]

101. Kontakiotis, G.; Antonarakou, A.; Zachariasse, W.J. Late Quaternary palaeoenvironmental changes in the Aegean Sea: Interrelations and interactions between North and South Aegean Sea. Bull. Geol. Soc. Greece 2013, 47, 167-177. [CrossRef]

102. Lirer, F.; Sprovieri, M.; Vallefuoco, M.; Ferraro, L.; Pelosi, N.; Giordano, L.; Capotondi, L. Planktonic foraminifera as bio-indicators for monitoring the climatic changes that have occurred over the past 2000 years in the southeastern Tyrrhenian Sea. Integr. Zool. 2014, 9, 542-554. [CrossRef]

103. Rohling, E.J.; Jorissen, F.J.; Grazzini, C.V.; Zachariasse, W.J. Northern Levantine and Adriatic Quaternary planktic foraminifera; Reconstruction of paleoenvironmental gradients. Mar. Micropaleontol. 1993, 21, 191-218. [CrossRef]

104. Marshall, B.J.; Thunell, R.C.; Henehan, M.J.; Astor, Y.; Wejnert, K.E. Planktonic foraminiferal area density as a proxy for carbonate ion concentration: A calibration study using the Cariaco Basin ocean time series. Paleoceanography 2013, 28, 363-376. [CrossRef]

105. Kucera, M.; Kennett, J. Causes and consequences of a Middle Pleistocene origin of the modern planktonic foraminifer Neogloboquadrina pachyderma sinistral. Geology 2002, 30, 539-542. [CrossRef]

106. Schneider, A.; Wallace, D.W.R.; Körtzinger, A. Alkalinity of the Mediterranean Sea. Geophys. Res. Lett. 2007, 34, L15608. [CrossRef]

107. Ujiié, Y.; Asami, T.; de Garidel-Thoron, T.; Liu, H.; Ishitani, Y.; de Vargas, C. Longitudinal differentiation among pelagic populations in a planktic foraminifer. Ecol. Evol. 2012, 2, 1725-1737. [CrossRef]

108. Kontakiotis, G. Palaeoceanographic and Palaeoclimatic Study of Eastern Mediterranean During Late Quaternary, Based on Planktonic Foraminiferal Assemblages. Ph.D. Thesis, National and Kapodistrian University of Athens, Athens, Greece, 2012. (In Greek, with English extended abstract).

109. Rigual-Hernández, A.S.; Sierro, F.J.; Bárcena, M.A.; Flores, J.A.; Heussner, S. Seasonal and interannual changes of planktic foraminiferal fluxes in the Gulf of Lions (NW Mediterranean) and their implications for paleoceanographic studies: Two 12-year sediment trap records. Deep Sea Res. Part I Oceanogr. Res. Pap. 2012, 66, 26-40. [CrossRef]

110. Tolderlund, D.S.; Allan, W.H.B. Seasonal Distribution of Planktonic Foraminifera in the Western North Atlantic. Micropaleontology 1971, 17, 297-329. [CrossRef]

111. Numberger, L.; Hemleben, C.; Hoffmann, R.; Mackensen, A.; Schulz, H.; Wunderlich, J.-M.; Kucera, M. Habitats, abundance patterns and isotopic signals of morphotypes of the planktonic foraminifer Globigerinoides ruber (d'Orbigny) in the eastern Mediterranean Sea since the Marine Isotopic Stage 12. Mar. Micropaleontol. 2009, 73, 90-104. [CrossRef]

112. Richey, J.N.; Poore, R.Z.; Flower, B.P.; Hollander, D.J. Ecological controls on the shell geochemistry of pink and white Globigerinoides ruber in the northern Gulf of Mexico: Implications for paleoceanographic reconstruction. Mar. Micropaleontol. 2012, 82-83, 28-37. [CrossRef]

113. Wejnert, K.E.; Pride, C.J.; Thunell, R.C. The oxygen isotope composition of planktonic foraminifera from the Guaymas Basin, Gulf of California: Seasonal, annual, and interspecies variability. Mar. Micropaleontol. 2010, 74, 29-37. [CrossRef]

114. D'Ortenzio, F.; Ragni, M.; Marullo, S.; Ribera d'Alcalà, M. Did biological activity in the Ionian Sea change after the Eastern Mediterranean Transient? Results from the analysis of remote sensing observations. J. Geophys. Res. Ocean. 2003, 108. [CrossRef]

115. D'Ortenzio, F.; Ribera d'Alcalà, M. On the trophic regimes of the Mediterranean Sea: A satellite analysis. Biogeosciences 2009, 6, 139-148. [CrossRef] 
116. Lavigne, H.; D'Ortenzio, F.; Ribera D'Alcalà, M.; Claustre, H.; Sauzède, R.; Gacic, M. On the vertical distribution of the chlorophyll a concentration in the Mediterranean Sea: A basin-scale and seasonal approach. Biogeosciences 2015, 12, 5021-5039. [CrossRef]

117. Gotsis-Skretas, O.; Pagou, K.; Moraitou-Apostolopoulou, M.; Ignatiades, L. Seasonal horizontal and vertical variability in primary production and standing stocks of phytoplankton and zooplankton in the Cretan Sea and the Straits of the Cretan Arc (March 1994-January 1995). Prog. Oceanogr. 1999, 44, 625-649. [CrossRef]

118. Malinverno, E.; Maffioli, P.; Corselli, C.; De Lange, G.J. Present-day fluxes of coccolithophores and diatoms in the pelagic Ionian Sea. J. Mar. Syst. 2014, 132, 13-27. [CrossRef]

119. Grilli, F.; Marini, M.; Book, J.W.; Campanelli, A.; Paschini, E.; Russo, A. Flux of nutrients between the middle and southern Adriatic Sea (Gargano-Split section). Mar. Chem. 2013, 153, 1-14. [CrossRef]

120. Takagi, H.; Kimoto, K.; Fujiki, T.; Saito, H.; Schmidt, C.; Kucera, M.; Moriya, K. Characterizing photosymbiosis in modern planktonic foraminifera. Biogeosciences 2019, 16, 3377-3396. [CrossRef]

121. Rohling, E.J.; Jorissen, F.J.; De Stigter, H.C. 200 Year interruption of Holocene sapropel formation in the Adriatic Sea. J. Micropalaeontol. 1997, 16, 97-108. [CrossRef]

122. Žarić, S.; Donner, B.; Fischer, G.; Mulitza, S.; Wefer, G. Sensitivity of planktic foraminifera to sea surface temperature and export production as derived from sediment trap data. Mar. Micropaleontol. 2005, 55, 75-105. [CrossRef]

123. Rohling, E.J.; Sprovieri, M.; Cane, T.; Casford, J.S.L.; Cooke, S.; Bouloubassi, I.; Emeis, K.C.; Schiebel, R.; Rogerson, M.; Hayes, A.; et al. Reconstructing past planktic foraminiferal habitats using stable isotope data: A case history for Mediterranean sapropel S5. Mar. Micropaleontol. 2004, 50, 89-123. [CrossRef]

124. Rasmussen, T.L.; Thomsen, E. Changes in planktic foraminiferal faunas, temperature and salinity in the Gulf Stream during the last 30,000 years: Influence of meltwater via the Mississippi River. Quat. Sci. Rev. 2012, 33, 42-54. [CrossRef]

125. Schiebel, R.; Hemleben, C. Interannual variability of planktic foraminiferal populations and test flux in the eastern North Atlantic Ocean (JGOFS). Deep Sea Res. Part II Top. Stud. Oceanogr. 2000, 47, 1809-1852. [CrossRef]

126. Machain, M.; Monreal-Gomez, M.; Arellano-Torres, E.; Merino-Ibarra, M.; Gonzalez-Chavez, G. Recent planktonic foraminiferal distribution patterns and their relation to hydrographic conditions of the Gulf of Tehuantepec, Mexican Pacific. Mar. Micropaleontol. 2008, 66, 103-119. [CrossRef]

127. Casford, J.S.L.; Rohling, E.J.; Abu-Zied, R.; Cooke, S.; Fontanier, C.; Leng, M.; Lykousis, V. Circulation changes and nutrient concentrations in the late Quaternary Aegean Sea: A nonsteady state concept for sapropel formation. Paleoceanography 2002, 17, 14-1-14-11. [CrossRef]

128. Hecht, A.D. Size variations in planktonic foraminifera: Implications for quantitative paleoclimatic analysis. Science 1976, 192, 1330-1332. [CrossRef]

129. Schmidt, D.N.; Lazarus, D.; Young, J.R.; Kucera, M. Biogeography and evolution of body size in marine plankton. Earth-Sci. Rev. 2006, 78, 239-266. [CrossRef]

130. Schmidt, D.N.; Thierstein, H.R.; Bollmann, J.; Schiebel, R. Abiotic forcing of plankton evolution in the Cenozoic. Science 2004, 303, 207-210. [CrossRef]

131. Bé, A.W.H.; Harrison, S.M.; Lott, L. Orbulina universa d'Orbigny in the Indian Ocean. Micropaleontology 1973, 19, 150-192. [CrossRef]

132. Hecht, A.D. An ecologic model for test size variation in recent planktonic foraminifera: Applications to the fossil record. $J$. Foraminifer. Res. 1976, 6, 295-311. [CrossRef]

133. Kennett, J.P. Phenotypic variation in some recent and late Cenozoic planktonic foraminifera. In Foraminifera; Hedley, R.H., Adams, C.G., Eds.; Academic Press: New York, NY, USA, 1976; Volume 2, pp. 111-170.

134. Malmgren, B.A.; Kennett, J.P. Size variations in Globigerina bulloides d'Orbigny as a Quaternary paleoclimatic index in the Southern Ocean. Antarct. J. 1976, 177-178.

135. Malmgren, B.A.; Kennett, J.P. Biometric differentiation between recent Globigerina bulloides and Globigerina falconensis in the southern Indian Ocean. J. Foraminifer. Res. 1977, 7, 130-148. [CrossRef]

136. Rillo, M.C.; Miller, C.G.; Kučera, M.; Ezard, T.H.G. Predictability of intraspecific size variation in extant planktonic foraminifera. bioRxiv 2018, 468165. [CrossRef]

137. Peter, K.; Sommer, U. Phytoplankton Cell Size Reduction in Response to Warming Mediated by Nutrient Limitation. PLoS ONE 2013, 8, e71528. [CrossRef]

138. Bé, A.W.H.; Caron, D.A.; Anderson, O.R. Effects of feeding frequency on life processes of the planktonic foraminifer Globigerinoides sacculifer in laboratory culture. J. Mar. Biol. Assoc. UK 1981, 61, 257-277. [CrossRef]

139. Takagi, H.; Kimoto, K.; Fujiki, T.; Moriya, K. Effect of nutritional condition on photosymbiotic consortium of cultured Globigerinoides sacculifer (Rhizaria, Foraminifera). Symbiosis 2018, 76, 25-39. [CrossRef]

140. Stambler, N. The Mediterranean Sea-Primary Productivity. In The Mediterranean Sea: Its History and Present Challenges; Goffredo, S., Dubinsky, Z., Eds.; Springer: Dordrecht, The Netherlands, 2014; pp. 113-121.

141. Bé, A.W.H.; Hutson, W.H. Ecology of Planktonic Foraminifera and Biogeographic Patterns of Life and Fossil Assemblages in the Indian Ocean. Micropaleontology 1977, 23, 369. [CrossRef]

142. Darling, K.F.; Wade, C.M. The genetic diversity of planktic foraminifera and the global distribution of ribosomal RNA genotypes. Mar. Micropaleontol. 2008, 67, 216-238. [CrossRef] 
143. de Vargas, C.; Zaninetti, L.; Hilbrecht, H.; Pawlowski, J. Phylogeny and rates of molecular evolution of planktonic Foraminifera: SSU rDNA sequences compared to the fossil record. J. Mol. Evol. 1997, 45, 285-294. [CrossRef]

144. Kucera, M.; Darling, K.F. Cryptic species of planktonic foraminifera: Their effect on palaeoceanographic reconstructions. Philos. Trans. Ser. A Math. Phys. Eng. Sci. 2002, 360, 695-718. [CrossRef] [PubMed]

145. Parker, F.L. Planktonic Foraminiferal Species in Pacific Sediments. Micropaleontology 1962, 8, 219-254. [CrossRef]

146. Darling, K.F.; Wade, C.M.; Kroon, D.; Brown, A.J.L.; Bijma, J. The Diversity and Distribution of Modern Planktic Foraminiferal Small Subunit Ribosomal RNA Genotypes and their Potential as Tracers of Present and Past Ocean Circulations. Paleoceanography 1999, 14, 3-12. [CrossRef]

147. de Vargas, C.; Bonzon, M.; Rees, N.W.; Pawlowski, J.; Zaninetti, L. A molecular approach to biodiversity and biogeography in the planktonic foraminifer Globigerinella siphonifera (d'Orbigny). Mar. Micropaleontol. 2002, 45, 101-116. [CrossRef]

148. Huber, R.; van Staaden, M.J.; Kaufman, L.S.; Liem, K.F. Microhabitat use, trophic patterns, and the evolution of brain structure in African cichlids. Brain Behav. Evol. 1997, 50, 167-182. [CrossRef] [PubMed]

149. Darling, K.F.; Wade, C.M.; Kroon, D.; Brown, A.J.L. Planktic foraminiferal molecular evolution and their polyphyletic origins from benthic taxa. Mar. Micropaleontol. 1997, 30, 251-266. [CrossRef]

150. Morard, R.; Quillévéré, F.; Escarguel, G.; Ujiie, Y.; de Garidel-Thoron, T.; Norris, R.D.; de Vargas, C. Morphological recognition of cryptic species in the planktonic foraminifer Orbulina universa. Mar. Micropaleontol. 2009, 71, 148-165. [CrossRef]

151. Vargas, C.d.; Norris, R.; Zaninetti, L.; Gibb, S.; Pawlowski, J. Molecular evidence of cryptic speciation in planktonic foraminifers and their relation to oceanic provinces. Proc. Natl. Acad. Sci. USA 1999, 96, 2864-2868. [CrossRef]

152. Morard, R.; Quillévéré, F.; Douady, C.J.; de Vargas, C.; de Garidel-Thoron, T.; Escarguel, G. Worldwide genotyping in the planktonic foraminifer Globoconella inflata: Implications for life history and paleoceanography. PLoS ONE 2011, 6, e26665. [CrossRef]

153. Aurahs, R.; Treis, Y.; Darling, K.; Kucera, M. A revised taxonomic and phylogenetic concept for the planktonic foraminifer species Globigerinoides ruber based on molecular and morphometric evidence. Mar. Micropaleontol. 2011, 79, 1-14. [CrossRef]

154. Seears, H.A.; Darling, K.F.; Wade, C.M. Ecological partitioning and diversity in tropical planktonic foraminifera. BMC Evol. Biol. 2012, 12, 54. [CrossRef] [PubMed]

155. Weiner, A.K.; Weinkauf, M.F.; Kurasawa, A.; Darling, K.F.; Kucera, M.; Grimm, G.W. Phylogeography of the tropical planktonic foraminifera lineage globigerinella reveals isolation inconsistent with passive dispersal by ocean currents. PLoS ONE 2014, 9, e92148. [CrossRef] [PubMed]

156. de Vargas, C.; Renaud, S.; Hilbrecht, H.; Pawlowski, J. Pleistocene Adaptive Radiation in Globorotalia truncatulinoides: Genetic, Morphologic, and Environmental Evidence. Paleobiology 2001, 27, 104-125. [CrossRef]

157. Quillévéré, F.; Morard, R.; Escarguel, G.; Douady, C.J.; Ujiié, Y.; de Garidel-Thoron, T.; de Vargas, C. Global scale same-specimen morpho-genetic analysis of Truncorotalia truncatulinoides: A perspective on the morphological species concept in planktonic foraminifera. Palaeogeogr. Palaeoclimatol. Palaeoecol. 2013, 391, 2-12. [CrossRef]

158. Darling, K.F.; Wade, C.M.; Stewart, I.A.; Kroon, D.; Dingle, R.; Brown, A.J. Molecular evidence for genetic mixing of Arctic and Antarctic subpolar populations of planktonic foraminifers. Nature 2000, 405, 43-47. [CrossRef]

159. Stewart, I.A.; Darling, K.F.; Kroon, D.; Wade, C.M.; Troelstra, S.R. Genotypic variability in subarctic Atlantic planktic foraminifera. Mar. Micropaleontol. 2001, 43, 143-153. [CrossRef]

160. André, A.; Quillévéré, F.; Schiebel, R.; Morard, R.; Howa, H.; Meilland, J.; Douady, C.J. Disconnection between genetic and morphological diversity in the planktonic foraminifer Neogloboquadrina pachyderma from the Indian sector of the Southern Ocean. Mar. Micropaleontol. 2018, 144, 14-24. [CrossRef]

161. Bauch, D.; Darling, K.; Simstich, J.; Bauch, H.A.; Erlenkeuser, H.; Kroon, D. Palaeoceanographic implications of genetic variation in living North Atlantic Neogloboquadrina pachyderma. Nature 2003, 424, 299-302. [CrossRef]

162. Darling, K.F.; Kucera, M.; Kroon, D.; Wade, C.M. A resolution for the coiling direction paradox in Neogloboquadrina pachyderma. Paleoceanography 2006, 21, PA2011. [CrossRef]

163. Darling, K.F.; Kucera, M.; Pudsey, C.J.; Wade, C.M. Molecular evidence links cryptic diversification in polar planktonic protists to Quaternary climate dynamics. Proc. Natl. Acad. Sci. USA 2004, 101, 7657. [CrossRef]

164. Darling, K.F.; Kucera, M.; Wade, C.M. Global molecular phylogeography reveals persistent Arctic circumpolar isolation in a marine planktonic protist. Proc. Natl. Acad. Sci. USA 2007, 104, 5002. [CrossRef] [PubMed]

165. Morard, R.; Vollmar, N.M.; Greco, M.; Kucera, M. Unassigned diversity of planktonic foraminifera from environmental sequencing revealed as known but neglected species. PLoS ONE 2019, 14, e0213936. [CrossRef] [PubMed]

166. Beer, C.J.; Schiebel, R.; Wilson, P.A. Testing planktic foraminiferal shell weight as a surface water $\left[\mathrm{CO}_{3}{ }^{2-}\right]$ proxy using plankton net samples. Geology 2010, 38, 103-106. [CrossRef]

167. Deuser, W.G.; Ross, E.H.; Hemleben, C.; Spindler, M. Seasonal changes in species composition, numbers, mass, size, and isotopic composition of planktonic foraminifera settling into the deep sargasso sea. Palaeogeogr. Palaeoclimatol. Palaeoecol. 1981, 33, 103-127. [CrossRef]

168. Ortiz, J.D.; Mix, A.C. The spatial distribution and seasonal succession of planktonic foraminifera in the California Current off Oregon, September 1987-September 1988. Geol. Soc. Lond. Spec. Publ. 1992, 64, 197-213. [CrossRef]

169. Salmon, K.H.; Anand, P.; Sexton, P.F.; Conte, M. Upper ocean mixing controls the seasonality of planktonic foraminifer fluxes and associated strength of the carbonate pump in the oligotrophic North Atlantic. Biogeosciences 2015, 12, 223-235. [CrossRef] 
170. Poore, R.Z.; Spear, J.W.; Tedesco, K.A. Seasonal flux and assemblage composition of planktic foraminifers from a sediment-trap study in the northern Gulf of Mexico. J. Coast. Res. 2013, 6-19. [CrossRef]

171. Chernihovsky, N.; Torfstein, A.; Almogi-Labin, A. Seasonal flux patterns of planktonic foraminifera in a deep, oligotrophic, marginal sea: Sediment trap time series from the Gulf of Aqaba, northern Red Sea. Deep Sea Res. Part I Oceanogr. Res. Pap. 2018, 140, 78-94. [CrossRef]

172. Jonkers, L.; Kučera, M. Global analysis of seasonality in the shell flux of extant planktonic Foraminifera. Biogeosciences 2015, 12, 2207-2226. [CrossRef] 